\title{
Temporal changes in ventilation and the carbonate system in the Atlantic sector of the Southern Ocean
}

\author{
Toste Tanhua $^{\mathrm{a}, *}$, Mario Hoppema ${ }^{\mathrm{b}}$, Elizabeth M. Jones ${ }^{\mathrm{c}}$, Tim Stöven ${ }^{\mathrm{a}}$, Judith Hauck ${ }^{\mathrm{b}}$, \\ Melchor González Dávila ${ }^{\mathrm{d}}$, Magdalena Santana-Casiano ${ }^{\mathrm{d}}$, Marta Álvarez ${ }^{\mathrm{e}}$, Volker H. Strass ${ }^{\mathrm{b}}$ \\ a GEOMAR Helmholtz Centre for Ocean Research Kiel, Düsternbrooker Weg 20, 24105 Kiel, Germany \\ b Alfred Wegener Institute Helmholtz Centre for Polar and Marine Research, Bremerhaven, Germany \\ ${ }^{\mathrm{c}}$ Centre for Energy and Environmental Sciences, University of Groningen, Groningen, The Netherlands \\ d Instituto de Oceanografia y Cambio Global, Universidad de Las Palmas de Gran Canaria, Spain \\ e Instituto Español de Oceanografía, A Coruña, Spain
}

\section{A R T I C L E I N F O}

\section{Keywords:}

Tracers

Carbon cycle

Southern ocean

\begin{abstract}
A B S T R A C T
The Southern Ocean is the most important area of anthropogenic carbon $\left(\mathrm{C}_{\mathrm{ant}}\right)$ uptake in the world ocean, only rivalled in importance by the North Atlantic Ocean. Significant variability on decadal time-scales in the uptake of $\mathrm{C}_{\mathrm{ant}}$ in the Southern Ocean has been observed and modelled, likely with consequences for the interior ocean storage of $\mathrm{C}_{\mathrm{ant}}$ in the region, and implications for the global carbon budget. Here we use eight cruises between 1973 and 2012 to assess decadal variability in $\mathrm{C}_{\text {ant }}$ storage rates in the southeast Atlantic sector of the Southern Ocean. For this we employed the extended multiple linear regression (eMLR) method. We relate variability in DIC (dissolved inorganic carbon) storage, which is assumed to equal anthropogenic carbon storage, to changes in ventilation as observed from repeat measurements of transient tracers. Within the Antarctic Intermediate Water (AAIW) layer, which is the dominant transport conduit for $\mathrm{C}_{\mathrm{ant}}$ into the interior ocean, moderate $\mathrm{C}_{\mathrm{ant}}$ storage rates were found without any clear temporal trend. In Subantarctic Mode Water (SAMW), a less dense water mass found north of the Subantarctic Front and above AAIW, high storage rates of $\mathrm{C}_{\text {ant }}$ were observed up to about 2005 but lower rates in more recent times. The transient tracer data suggest a significant speed-up of ventilation in the summer warmed upper part of AAIW between 1998 and 2012, which is consistent with the high storage rate of $\mathrm{C}_{\mathrm{ant}}$. A shift of more northern $\mathrm{C}_{\mathrm{ant}}$ storage to more southern storage in near surface waters was detected in the early 2000s. Beneath the AAIW the eMLR method as applied here did not detect significant storage of $\mathrm{C}_{\mathrm{ant}}$. However, the presence of the transient tracer CFC-12 all through the water column suggests that some $\mathrm{C}_{\text {ant }}$ should be present, but at concentrations not reliably quantifiable. The observed temporal variability in the interior ocean seems at a first glance to be out of phase with observed surface ocean $\mathrm{C}_{\text {ant }}$ fluxes, but this can be explained by the time delay for the surface ocean signal to manifest itself in the interior of the ocean.
\end{abstract}

\section{Introduction}

Since the Industrial Revolution, mankind has accelerated changes to the global carbon cycle by releasing huge amounts of carbon dioxide $\left(\mathrm{CO}_{2}\right)$ into the atmosphere, primarily from fossil fuel combustion and land use change. This is particularly harmful because a higher $\mathrm{CO}_{2}$ level in the atmosphere will enhance the greenhouse effect of the atmosphere, leading to a rise in global temperature and other changes. Fortunately for global climate, the global ocean is taking up a significant portion $(\sim 30 \%)$ of the excess $\mathrm{CO}_{2}$ from the atmosphere ( 155 Pg C through year 2010 (Khatiwala et al., 2013;)) thus diminishing some of the forcing of the greenhouse effect. The Southern
Ocean has taken up, and stored, disproportionate amounts of anthropogenic $\mathrm{CO}_{2}$ (e.g. Mikaloff Fletcher et al., 2006; Khatiwala et al., 2009; Takahashi et al., 2009; Lenton et al., 2013; Frölicher et al., 2015). Khatiwala et al. (2009) estimated the uptake south of $44^{\circ} \mathrm{S}$ to be $0.7 \mathrm{Pg} \mathrm{C} \mathrm{yr}^{-1}$, i.e. about one third of the total oceanic sink. A study by Le Quéré et al. (2007) identified a trend of decreasing $\mathrm{CO}_{2}$ uptake by the Southern Ocean, suggested to be caused by enhanced vertical transfer upwelling of $\mathrm{CO}_{2}$-charged subsurface water into the surface layer. An investigation including more recent data from the surface ocean spotted the end of this decreasing trend of $\mathrm{CO}_{2}$ uptake in 2002 and by 2012 a full reinvigoration of the $\mathrm{CO}_{2}$ uptake had taken place (Landschützer et al., 2015). Apparently, the dynamics of the carbon

\footnotetext{
* Corresponding author at: GEOMAR Helmholtz Centre for Ocean Research Kiel, Düsternbrooker Weg 20, 24105 Kiel, Germany.

E-mail address: ttanhua@geomar.de (T. Tanhua).
} 
cycle of the Southern Ocean contain some surprising aspects which requires close observation.

Uptake of $\mathrm{CO}_{2}$ occurs at the air-sea interface. As a consequence, the greatest part of anthropogenic $\mathrm{CO}_{2}$ is stored in the surface layer from where it can be transported to the ocean interior. The uptake capacity of the oceanic surface layer will decrease further into the future due to the Revelle effect and climate feedbacks (e.g Sabine and Tanhua, 2010) although biological carbon draw-down might be more important in the future (Hauck and Völker, 2015). The large $\mathrm{CO}_{2}$ storage capacity of the global oceans is not well exploited because of the sluggish mixing and water exchange between the surface water, where the uptake occurs, and the interior layers. In this respect the Southern Ocean is a vital region because of the close connection between all water layers, thus to a certain extent bridging a sluggish-mixing gap. In the Weddell Sea, very dense surface waters on the extensive shelves store anthropogenic $\mathrm{CO}_{2}$, which is brought into the deep water layers during formation of Weddell Sea Bottom Water and Antarctic Bottom Water (AABW). This dense $\mathrm{AABW}$, enriched in anthropogenic $\mathrm{CO}_{2}$, leaves the Weddell Gyre thus contributing to global $\mathrm{CO}_{2}$ sequestration on a centennial timescale. Ventilated AABW populates a major part of the bottom layers of the global oceans. Within the Weddell Gyre, anthropogenic $\mathrm{CO}_{2}$ has been detected all through the water column (van Heuven et al., 2011; Huhn et al., 2013; Pardo et al., 2014).

A different, and more important, pathway of $\mathrm{CO}_{2}$ sequestration in the Southern Ocean is via the formation of Antarctic Intermediate Water (AAIW) and Subantarctic Mode Water (SAMW) in the northern part of the ACC. Surface water moving northward absorbs anthropogenic $\mathrm{CO}_{2}$, and subducts to form AAIW and SAMW that are separated from the surface layer near the Subantarctic Front (SAF). This is the main region for uptake and sequestration of anthropogenic $\mathrm{CO}_{2}$ in the Southern Ocean (Caldeira and Duffy, 2000; Sabine et al., 2004; Gruber et al., 2009). Ventilated and anthropogenic $\mathrm{CO}_{2}$-charged AAIW occupies the greater portion of the intermediate water layers of the Southern Hemisphere and even reaches further northward to subtropical latitudes of the Northern Hemisphere. Climate change in the form of modified wind tracks may via sea-ice export lead to changes in AAIW formation (Abernathey et al., 2016) and its uptake of anthropogenic $\mathrm{CO}_{2}$.

The Antarctic Circumpolar Current (ACC) is the major circulation feature of the Southern Ocean and the brawniest current in the world oceans. Its high relevance for global climate is self-evident: This pertains to transport and distribution of heat and fresh water as well as chemical compounds and gases. The ACC is not a continuous, eastward flowing, uniform current, but rather consists of several strong jets alternating with calmer regions (Whitworth and Nowlin, 1987; Orsi et al., 1995; Sokolov and Rintoul, 2009). The jets are typically associated with oceanographic fronts - from north to south we distinguish (see Strass et al., 2016) the Subantarctic Front (SAF), the Antarctic Polar Front (APF), the Southern Polar Front and the Southern Boundary, the latter of which is the transition to the Weddell Gyre to the south (see Fig. 1).

The surface layer of the Southern Ocean consists of Antarctic Surface Water (AASW) in the south and Subantarctic Surface Water (SASW) in more northern regions. The divide between the two is formed by the APF. South of the front, the surface water reaches the freezing point in winter and sea ice is formed. North of the APF, a strong gradient of increasing surface temperature is observed towards the subtropical region. Between the APF and the SAF extends a belt of minimum surface salinities, which result from excess precipitation in this region and sea ice melt, and coin the salinity minimum that characterizes the AAIW after its subduction at the SAF. North of the SAF, deep mixed layers in winter generate Subantarctic Mode Water (e.g. McCartney, 1977; Tsuchiya et al., 1994). From the north, North Atlantic Deep Water (NADW) joins the ACC off South America; it can be identified as a wedge of water characterized by high salinity, high oxygen and low nutrient, CFC-12 and DIC content at roughly 3000-
$4000 \mathrm{~m}$ depth shoaling from north to south (e.g. Whitworth and Nowlin, 1987; Whitworth et al., 1991). NADW forms the main supply of the Lower Circumpolar Deep Water (LCDW), the most voluminous water mass of the ACC. The other part of the Circumpolar Deep Water, namely Upper Circumpolar Deep Water (UCDW), is characterized by an oxygen minimum and high nutrient concentrations compared to the NADW due to their longer circulation path from its origin in the deep waters of the Indian and Pacific oceans (Peterson and Whitworth, 1989; Tsuchiya et al., 1994).

South of the ACC lies the Weddell Gyre, an elongated cyclone with clockwise flow (Fig. 1). A main connection between the ACC to the north and the Weddell Gyre to the south is the inflow of Circumpolar Deep Water (CDW) into the gyre. The CDW is the dominant water and heat supply to the Weddell Gyre from which almost all other water masses in the gyre are derived. The CDW is locally known as Warm Deep Water (WDW) because of its temperature maximum below the surface layer. Within the Weddell Gyre, WDW is upwelled into the surface layer, thus shaping the features of the latter (Gordon and Huber, 1990). Along the margins, WDW also feeds into deep and bottom water formation leading to AABW as one of the mixing components, together with denser surface waters.

Ventilation processes, such as occurring in the Weddell Sea and northern ACC, are instrumental for the uptake and sequestration of anthropogenic $\mathrm{CO}_{2}$. The degree of ventilation, as well as changes in ventilation, has major impacts on the future trend of the mass balance of oceanic $\mathrm{CO}_{2}$. The transport of surface water into the ocean interior can be investigated by using transient tracers such as CFCs and $\mathrm{SF}_{6}$. These tracers provide time information about ventilation processes since the atmospheric growth rate of these tracers is also reflected in the tracer concentration in the ocean interior due to the gas exchange between the atmosphere and the ocean (e.g. Fine, 2011). This time information can then be used to determine current states of ventilation and in the case of transient tracer time series also changes or trends in ventilation.

There are still many unknowns related to the ocean carbon cycle, particularly to that of the Southern Ocean, and its anthropogenic perturbation. Part of this is caused by the scarcity of data in this remote and relatively inaccessible region. High spatial variability in different processes appears to have a major impact on the uptake of $\mathrm{CO}_{2}$ from the atmosphere, as recently demonstrated by Landschützer et al. (2015). Water mass formation occurs in restricted areas of the Southern Ocean, which accentuates the dependence on smaller-scale processes and its variability for water mass formation. Here we utilize new $\mathrm{CO}_{2}$ and auxiliary data along a section at $10^{\circ} \mathrm{E}$ crossing the ACC between $44^{\circ}$ and $53^{\circ} \mathrm{S}$ near the northern boundary of the Weddell Gyre. Combining these new data with data that have been collected in the previous decades we investigate changes in local and regional dissolved inorganic carbon (DIC). This enables insights as to the anthropogenic impact on the carbon cycle. Implications for the wider Southern Ocean are discussed. This effort constituted part of the field work of the "Eddy-Pump" project (Wolf-Gladrow, 2013; Strass et al., 2016), and targeted measurements of biogeochemical and physical processes in and around Southern Ocean eddies, although this study focuses on temporal changes along a meridional section. The $\mathrm{CO}_{2}$ uptake around eddies has been addressed in a separate study (Jones et al., 2016). For a more detailed description of the hydrography including water masses and fronts at the $10^{\circ} \mathrm{E}$ section, see Strass et al. (2016).

\section{Material and methods}

\subsection{Cruise data}

In this work we analyze transient tracer and carbonate system data from the South Atlantic/Southern Ocean, focusing on a section along $10^{\circ} \mathrm{E}$ between 44 and $53^{\circ} \mathrm{S}$. Not only is this an area of formation of AAIW, it is also relatively well sampled for carbonate system variables 


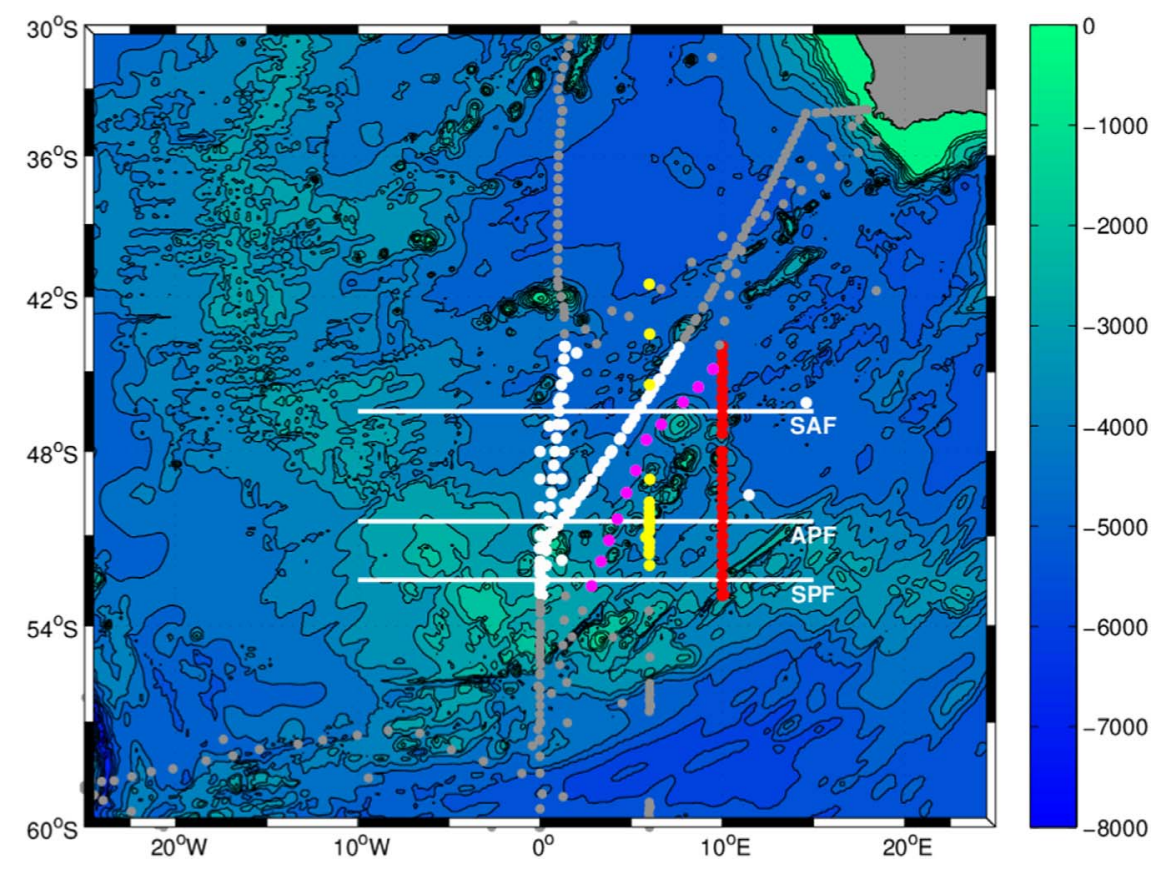

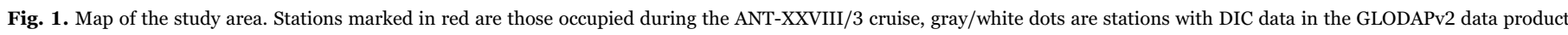

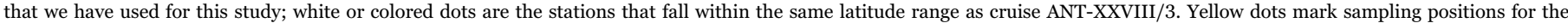

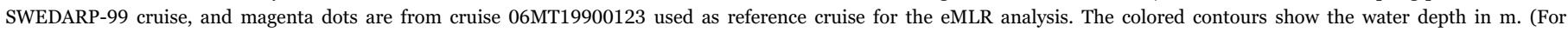
interpretation of the references to color in this figure legend, the reader is referred to the web version of this article.)

since the early 1970s. We combine data from a recent cruise, ANTXXVIII/3 (2012) with historic cruises in the same area taken from the global synthesis, GLODAPv2 (Olsen et al., 2016). The 2012 data were collected with the German ice breaker FS Polarstern on cruise ANTXXVIII/3 (expocode 06AQ20120107) from Cape Town (South Africa) to Punta Arenas (Chile), 7 January to 11 March 2012. The measurements during the ANT-XXVIII/3 cruise include the transient tracers $\mathrm{SF}_{6}$ and CFC-12 (Stöven et al., 2015), the carbonate system variables Dissolved Inorganic Carbon (DIC) and Total Alkalinity (TA) (Jones et al., 2016), the inorganic macronutrients silicate, nitrate and phosphate (Hoppe et al., 2016) as well as dissolved oxygen. Oxygen was measured using a standard automated Winkler technique with photometric endpoint detection with a precision of $0.7 \mu \mathrm{mol} / \mathrm{kg}$, or $0.3 \%$. The data are available at CDIAC: http://cdiac.ornl.gov/ftp/oceans/ CLIVAR/A12_06AQ20120107/.

The historic data set was extracted from the GLODAPv2 data product (Olsen et al., 2016). Cruises were selected that sampled between $5^{\circ} \mathrm{W}$ and $15^{\circ} \mathrm{E}$ and $44^{\circ}$ and $53^{\circ} \mathrm{S}$ that had more than a couple of stations in this meridional range and contained oxygen, nutrients, DIC and TA data; this resulted in a collection of 7 historic cruises (Table 1). We choose to compare stations at similar latitude although separated in the east-west direction by up to $10^{\circ}$ based on the fact that fronts etc. tend to be zonal in extent in the ACC, and with the knowledge that zonal gradients are orders of magnitude smaller than meridional gradients. The spatial distribution of all samples is shown in Fig. 1. In addition to these cruises we also use CFC-12 data from the Swedish Antarctic Research Programme (SWEDARP) 1997/1998 expedition (Tanhua et al., 2004). These data are not part of the GLODAPv2 collection but were quality controlled as part of the CARINA synthesis (Key et al., 2010).

An important aspect of the GLODAPv2 data used in this study is that these have undergone critical consistency control so that any biases in the measured variables have been eliminated by applying adjustments to the data (Olsen et al., 2016). The consistency control is mainly based on comparison of values in layers with minimum temporal variability, so called cross-over analysis (Tanhua et al., 2010). Adjustments applied to the data sets in the GLODAPv2 product are listed in Table 1. Motivation for, and discussion of, the adjustments made to these cruises can be found on the GLODAPv2 website http:// cdiac.ornl.gov/oceans/GLODAPv2/cruise_table.html. Details and references for the cruises used are listed in Table 1.

For this study we also use modern and historic transient tracer data for the survey area. This includes: $\mathrm{SF}_{6}$ and $\mathrm{CFC}-12$ data from the ANTXXVIII/3 expedition in 2012 (discussed below); historic CFC-12 data from the SWEDARP expedition in 1998 (Tanhua et al., 2004) and the ANT-XV/4 expedition in 1998 (Hoppema et al., 2001). Here we report the partial pressure of the transient tracers rather than the concentration, since the former is the relevant unit for quantification of ventilation. For calculation of the partial pressure, we used the solubility functions of Warner and Weiss (1985) and Bullister et al. (2002).

\subsection{Tracer age and time-lag analysis}

The tracer age $\tau$ is based on a purely advective transport of the boundary condition of the tracer (normally its atmospheric concentration) into the ocean's interior. The time-dependent boundary conditions $\mathrm{C}_{0}\left(\mathrm{t}_{\text {hist }}\right)$ of $\mathrm{CFC}-12$ and $\mathrm{SF}_{6}$ are a function of the corresponding atmospheric histories and the surface saturation state of the gases. The measured tracer concentration $\mathrm{C}\left(\mathrm{t}_{\mathrm{s}}\right)$ in sampling year $\mathrm{t}_{\mathrm{s}}$ is compared with a specific surface ocean boundary condition (i.e. the combination of atmospheric history and ocean saturation state) in year $t_{\text {hist }}$ (Eq. (1)) and when they are equal, the difference between both years is the tracer age of the water sample measured at time $t_{s}$ (Eq. (2)). The atmospheric histories of CFC-12 and $\mathrm{SF}_{6}$ are taken from Bullister (2015).

$\mathrm{C}\left(\mathrm{t}_{\mathrm{s}}\right)=\mathrm{C}_{0}\left(\mathrm{t}_{\text {hist }}\right)$

$\tau=t_{\mathrm{s}}-\mathrm{t}_{\text {hist }}$

Since purely advective flows are not realistic in the ocean due to presence of mixing processes, the tracer age approach has largely been abandoned and replaced by more refined models such as the transit time distribution that take the effect of mixing into account (Hall and Plumb, 1994; Waugh et al., 2003). Nevertheless, the tracer age of CFC12 and $\mathrm{SF}_{6}$ can still be useful for the so-called time-lag analysis 
Table 1

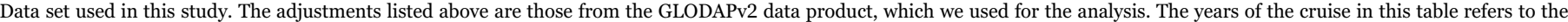

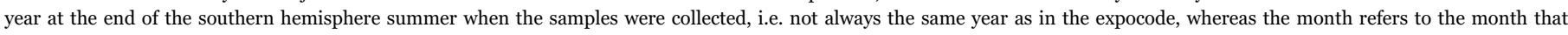
observations were carried out. Adjustments for DIC and TA are additive whereas adjustments for oxygen and nutrients are multiplicative (Tanhua et al., 2010).

\begin{tabular}{|c|c|c|c|c|}
\hline Expocode / year & Project & Carbon PI & Adjustments in GLODAPv2 & References \\
\hline 316N19720718 1973/Jan & GEOSECS leg 7 & T. Takahashi & $\begin{array}{l}\text { TA: }-7 \mu \mathrm{mol} \mathrm{kg} \\
\mathrm{O}_{2}: 0.99 \\
\mathrm{NO}_{3}: 1.02 \\
\mathrm{PO}_{4}: 1.025\end{array}$ & (Bainbridge, 1981; Peng and Wanninkhof, 2010) \\
\hline 316N19831007 1984/Oct, Jan & AJAX & $\begin{array}{l}\text { T. Takahashi } \\
\text { D. Chipman }\end{array}$ & $\begin{array}{l}\text { DIC: } 8 \\
\text { TA: } 4 \mu \mathrm{mol} \mathrm{kg}^{-1} \\
\mathrm{O}_{2}: 0.99 \\
\mathrm{PO}_{4}: 0.98 / 1.02\end{array}$ & (Nierenberg and Nowlin, 1985; Chipman et al., 1986) \\
\hline 06MT19900123 1990/Feb & WOCE A12 & T. Takahashi & $\begin{array}{l}\text { TA: } 4 \mu \mathrm{mol} \mathrm{kg}-1 \\
\mathrm{O}_{2}: 0.99 \\
\mathrm{NO}_{3}: 0.985 \\
\mathrm{PO}_{4}: 0.98 \\
\mathrm{Si}: 0.96\end{array}$ & (Chipman et al., 1994) \\
\hline 91AA19971204 1998/Jan & SWEDARP & $\begin{array}{l}\text { M. Chierici } \\
\text { A. Fransson }\end{array}$ & Only CFC-12 data used & (Tanhua et al., 2004) \\
\hline 06AQ19980328 1998/May & $\begin{array}{l}\text { WOCE A12 } \\
\text { ANT-XV/4 }\end{array}$ & $\begin{array}{l}\text { M. Hoppema } \\
\text { R. Bellerby }\end{array}$ & $\begin{array}{l}\text { DIC: }-3 \mu \mathrm{mol} \mathrm{kg}^{-1} \\
\mathrm{O}_{2}: 1.005 \\
\text { TA: not measured }\end{array}$ & (Hoppema et al., 2001; Hoppema, 2004) \\
\hline 90AV20041104 2005/Nov & GoodHope & M. Álvarez & $\begin{array}{l}\mathrm{PO}_{4}: 0.99 \\
\mathrm{Si}: 1.02 \\
\mathrm{NO}_{3}: \text { discarded } \\
\text { DIC: calculated }\end{array}$ & (Gladyshev et al., 2008) \\
\hline 35MF20080207 20008/Feb, Mar & BONUS-GoodHope & $\begin{array}{l}\text { M. Gonzalez- Davila } \\
\text { B. Delille }\end{array}$ & $\begin{array}{l}\mathrm{O}_{2}: 0.995 \\
\text { Si: } 0.97\end{array}$ & (González-Dávila et al., 2011) \\
\hline 33RO20100308 2010/Mar & GO-SHIP A13.5 & $\begin{array}{l}\text { R. Wanninkhof } \\
\text { R. Feely } \\
\text { A. Dickson }\end{array}$ & & (Stöven et al., 2015) \\
\hline
\end{tabular}

method. Time-lag analysis is used to detect changes in ventilation but it does not give any constrained time information about the ventilation process itself, and thus is independent of any assumptions on ocean mixing processes (Tanhua et al., 2013). This method is based on the fact that $\mathrm{CFC}-12$ and $\mathrm{SF}_{6}$ have similar rates of increase in the atmosphere but with an offset of about 14 years. Assuming similar saturation of both tracers in the surface water at the time of ventilation, a steady ventilation process would result in the same tracer age determined from $\mathrm{SF}_{6}$ data collected during a recent cruise (here 2012) as that determined from CFC-12 data collected during a historic cruise 14 years previously (here 1998). Consequently, a difference in the tracer age between modern $\mathrm{SF}_{6}$ and historic CFC-12 data $(\Delta \tau)$ indicates change in ventilation (Eq. 3 ).

$\Delta \tau=\tau_{\mathrm{SF} 6, \text { modern }}-\mathrm{t}_{\mathrm{CFC}-12, \text { historic }}$

A slowing down of the ventilation would lead to positive $\Delta \tau$ values and elevated ventilation to negative $\Delta \tau$ values. Although simple in concept and less prone to systematic biases, this method is restricted by the limited availability of data sets covering the same region and with the required 14 year time-lag.

\section{3. extended Multiple Linear Regression (eMLR)}

Quantification of annual to decadal changes of DIC, and potentially other biogeochemical variables, can be performed through repeat measurements along hydrographic sections. Observed changes, i.e. an increase in DIC concentration can be interpreted as a result of uptake of anthropogenic $\mathrm{CO}_{2}$ through air-sea exchange with an atmosphere with increasing $\mathrm{CO}_{2}$ concentrations. However, the DIC concentration in the interior ocean is also a function of the amount of organic matter that is oxidized, particularly in the upper $\sim 1000 \mathrm{~m}$ where remineralization of organic carbon preferentially occurs (i.e. Henson et al., 2012). The remineralization of organic matter consumes oxygen, so that changes in the rate of remineralization can be quantified by changes in oxygen utilization, assuming no temporal change in the surface oxygen saturation occurred. Variations in remineralization can be a function of changes in ventilation processes, which is the main transport pathway of dissolved organic matter, or a change in the downward flux of particulate organic matter either due to fluctuations in particle flux rate (possibly as a function of particle composition and size), or variation in the total flux of particles due to changes in productivity. These processes are difficult to separate, although transient tracer data can provide information about changes in ventilation. We have chosen not to differentiate changes in DIC that result from changes in remineralization from changes due to increasing atmospheric $\mathrm{CO}_{2}$ concentration, similarly to e.g. Friis et al. (2005); Tanhua et al. (2007); and Wanninkhof et al. (2010), but differently from e.g. Sabine et al. (2008); Álvarez et al. (2011); and Williams et al. (2015). The reason is that the primary quantity we are interested in is the change in the ocean inventory of carbon that can offset the anthropogenic $\mathrm{CO}_{2}$ increase in the atmosphere. We do however use available transient tracer data to quantify changes in ventilation, see Section 3.1. The quantification of the temporal change in DIC over time is complicated by natural, spatiotemporal variability caused by, for instance, the presence of non-stationary eddies and fronts, so that a direct comparison of DIC concentrations from two repeats is inconclusive, or "patchy" (e.g. Wanninkhof et al., 2010). Such variability can to some extent be compensated for by using multiple linear regression (MLR) analysis (Wallace, 1995) or a variation thereof, the extended MLR (eMLR) as introduced by Friis et al. (2005). The MLR based 

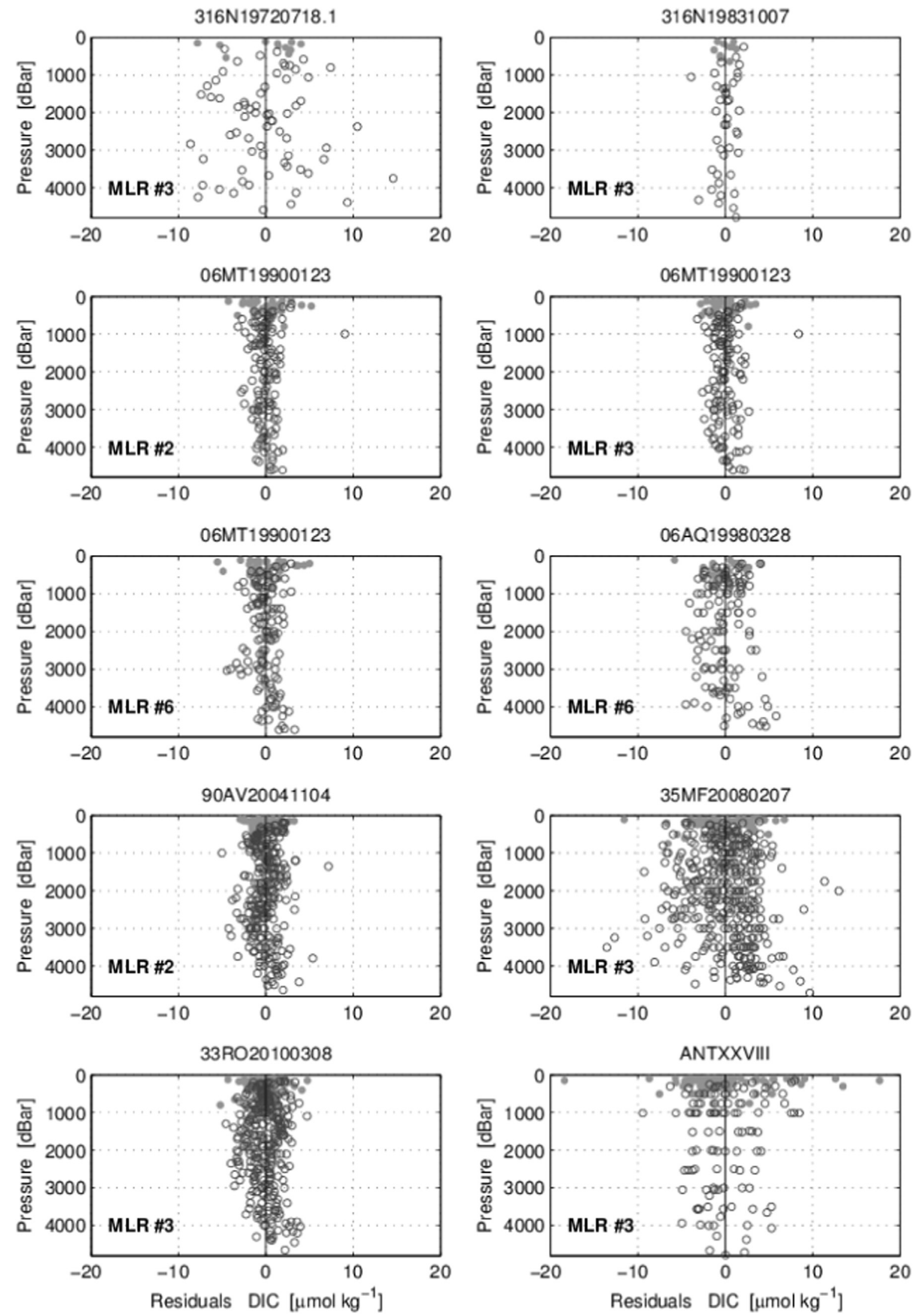

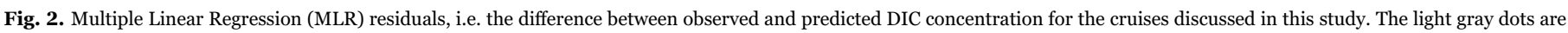

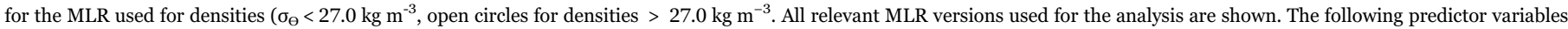
were used: MLR\#2 - S, T, Talk, Si, and $\mathrm{O}_{2}, \mathrm{MLR} \# 3-\mathrm{S}$, T, Talk, $\mathrm{NO}_{3}$ and $\mathrm{O}_{2}, \mathrm{MLR} \# 6-\mathrm{T}, \mathrm{S}, \mathrm{NO}_{3}, \mathrm{Si}$, and $\mathrm{O}_{2}$. 
Table 2

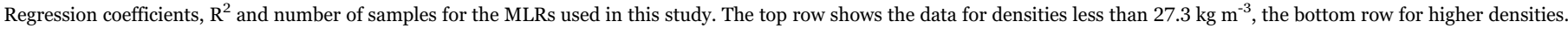

\begin{tabular}{|c|c|c|c|c|c|c|c|c|}
\hline Cruise & Theta & Salinity & TA & Nitrate & Oxygen & Silicate & $\mathbf{R}^{2}$ & $\mathbf{n}$ \\
\hline $316 N 19720718$ & -29.25 & -26.47 & 0.19 & -7.23 & -1.47 & - & 0.969 & 11 \\
\hline MLR\#3 & -6.75 & 94.63 & 0.16 & 6.20 & -0.03 & - & 0.899 & 67 \\
\hline 316N19831007 & -6.13 & 14.53 & 0.95 & 2.52 & -0.26 & - & 0.999 & 11 \\
\hline MLR\#3 & -7.64 & -29.30 & 0.82 & 1.12 & -0.52 & - & 0.995 & 46 \\
\hline 06MT19900123 & -13.05 & 50.23 & 0.73 & - & -0.30 & -0.02 & 0.993 & 39 \\
\hline MLR\#2 & -8.95 & -27.52 & 0.44 & - & -0.65 & 0.20 & 0.991 & 128 \\
\hline 06 MT19900123 & -8.49 & 40.58 & 0.82 & 1.60 & -0.19 & - & 0.996 & 39 \\
\hline MLR\#3 & -11.47 & -17.23 & 0.58 & 0.92 & -0.60 & - & 0.991 & 128 \\
\hline 06MT19900123 & -0.71 & -0.67 & - & 2.84 & -0.16 & 1.08 & 0.992 & 40 \\
\hline MLR\# 6 & -8.23 & 0.78 & - & 0.28 & -0.61 & 0.41 & 0.990 & 129 \\
\hline 06AQ19980328 & -6.67 & 1.29 & - & 1.00 & -0.50 & 0.57 & 0.992 & 28 \\
\hline MLR\#6 & -5.63 & 1.02 & - & 0.31 & -0.56 & 0.43 & 0.978 & 212 \\
\hline 90AV20041104 & -9.88 & 21.73 & 0.68 & - & -0.41 & 0.07 & 0.996 & 50 \\
\hline MLR\#2 & -11.71 & -54.77 & 0.85 & - & -0.65 & -0.07 & 0.987 & 260 \\
\hline 35MF20080207 & -10.07 & 11.53 & 0.66 & 0.21 & -0.38 & - & 0.982 & 72 \\
\hline MLR\#3 & -15.43 & 13.73 & 0.18 & 1.44 & -0.56 & - & 0.919 & 369 \\
\hline 33RO20100308 & -13.32 & 28.01 & 0.29 & -0.54 & -0.46 & - & 0.995 & 69 \\
\hline MLR\#3 & -10.30 & 19.90 & 0.31 & 2.72 & -0.40 & - & 0.984 & 306 \\
\hline 06AQ20120107 & -7.92 & 48.71 & 0.19 & 1.98 & -0.13 & - & 0.959 & 72 \\
\hline MLR\#3 & -6.11 & 36.59 & 0.34 & 4.23 & -0.21 & - & 0.948 & 111 \\
\hline
\end{tabular}

techniques can also compensate for the fact that we are comparing cruises that are not exact repeat stations as described in Section 2.1. The eMLR technique is based on finding independent variables that together serve to describe the DIC concentration of the water samples for both time periods:

$D I C_{M L R}=a_{1}+b_{1} V 1+c_{1} V 2+\ldots+n_{1} V n$

where $a_{1}$ to $n_{1}$ are the coefficients for variables $V 1$ to $V n$ which are used to describe the system. A similar regression is then determined for another cruise in a different year, and the coefficients $\mathrm{a}_{2}$ to $\mathrm{n}_{2}$ for the same variables are subtracted from the original coefficients $\left(a_{1}\right.$ to $\left.a_{n}\right)$ yielding a new set of coefficients. When the calculated coefficients are applied to the independent variables, the results can be interpreted as the change in DIC (assumed to equal change in $\mathrm{C}_{\mathrm{ant}}$ ) over this time period between the two cruises under comparison - the changes can be either positive or negative depending on whether the eMLR is applied in a "forward" or "backward" manner (Friis et al., 2005). The eMLR can be formulated as:

$D I C_{e M L R}=\left(a_{1}-a_{2}\right)+\left(b_{1}-b_{2}\right) V 1+\left(c_{1}-c_{2}\right) V 2+\ldots+\left(n_{1}-n_{2}\right) V n$

where the coefficients $\mathrm{a}_{2}$ to $\mathrm{n}_{2}$ are the coefficients from the second cruise. Here we used the 1990 cruise as reference cruise, and apply the eMLR either in forward or backward manner depending on whether the second cruise was performed before or after 1990 .

The MLR (and eMLR) method is sensitive to the selection of the suite of independent variables for the MLR; different selections frequently bias the result. Limitations and advantages of the eMLR technique have been discussed by, e.g. Tanhua et al., 2007; Levine et al., 2008; Wanninkhof et al., 2010; Plancherel et al., 2012; Thacker, 2012). The eMLR technique inherently makes the assumption of a steady-state ocean, which is generally not the reality, particularly for surveys separated by several decades in time, or for surveys in areas affected by significant climate variability. Goodkin et al. (2011) conclude that a sampling interval exceeding 30 years in the Southern Ocean may cause an error exceeding $20 \%$ in the $\triangle D I C$ determined by the eMLR method, as further explored by Hauck and Völker (2015). In summary, the eMLR method is useful for quantifying the (expected) increase in oceanic DIC concentration, but with a number of caveats that needs to be considered. We choose to use the eMLR method to discuss the storage rate of anthropogenic $\mathrm{CO}_{2}$ for comparison with the rich literature using this method even though the use of other methods may be considered.

A number of different multiple linear regression (MLR) formulations for determining the DIC concentration as a function of predictor variables were examined by plotting the MLR residual (i.e. the difference between measured and predicted DIC concentration) vs. depth. Particular focus was on avoiding depth dependent biases in the residual, and the precision of the prediction, i.e. the amount of scatter. A particular MLR can be optimized for a particular water mass with a certain formation history and biogeochemical relations, but is more difficult to define for a range of water masses. In this study we chose to create two different MLRs where the samples were divided by the potential density anomaly $27.3 \mathrm{~kg} \mathrm{~m}^{-3}$, which corresponds to the lower boundary of the AAIW. Dividing into more density layers could have been feasible, but the generally low number of samples for the relatively short sections that we have creates less well constrained MLR relations; we found that a division between "upper" and "lower" water masses was feasible and, in general, produced residuals with little depth dependency and small magnitude, criteria that we used to judge the "goodness" of a specific MLR formulation. Similarly, water samples from the surface layers (above $100 \mathrm{~m}$ depth) are affected by biological processes and air-sea exchange and are excluded from the MLR analysis. We found that using MLRs with the predictor variables salinity, temperature, alkalinity, nitrate and oxygen were most favorable using those criteria; this is referred to as MLR\#3. However, cruise 06AQ19980328 did not have alkalinity data, so for this cruise we used MLRs based on salinity, temperature, nitrate, silicate and oxygen; referred to as MLR\#6. Similarly, cruise 90AV20041104 did not have nitrate data so we used the predictor variables salinity, temperature, alkalinity, silicate and oxygen, referred to as MLR\#2. Fig. 2 shows the residuals for all MLRs used in this study and Table 2 shows the regression coefficients and some basic statistics.

We analyzed interior ocean carbon data from 8 cruises in the period spanning 1973-2012, i.e., 39 years. As discussed above, eMLR analysis can be biased if the cruises are separated by more than a few decades (Goodkin et al., 2011; Hauck and Völker, 2015); this might be a problem for the time-span we are working with here. However, we circumvent this drawback by running the eMLR analysis both forward and backward in time (Friis et al., 2005), and choosing one cruise in about the middle of the time span as a reference. It is usually favorable to take a cruise with measurements of high precision as the reference cruise. The precision can be judged by the magnitude of the residuals for the individual MLRs for the various cruises (provided the same MLR formulation is used). Cruise 06MT19900123 has a very low residual (i.e. precise data), a good data coverage in the region, and was conducted roughly in the middle of the time period we are considering. Therefore, we have referenced the 7 other cruises against this cruise so 

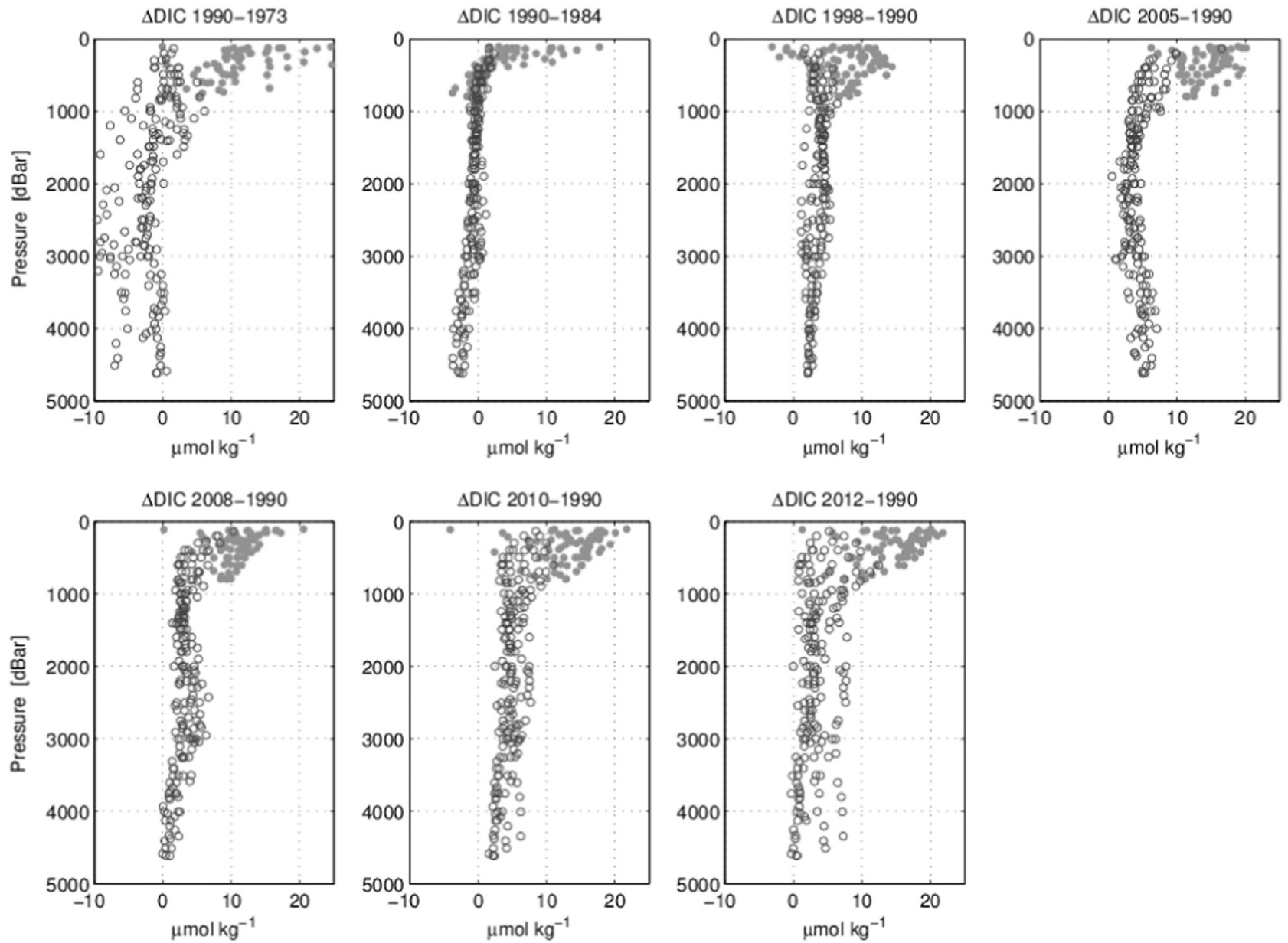

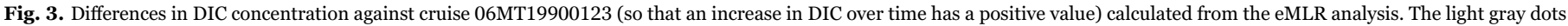
are for $\sigma_{\Theta}<27.3 \mathrm{~kg} \mathrm{~m}^{-3}$, the open circles for higher densities.

that older cruises are analyzed in "forward" mode, and the younger cruises are analyzed in "backward" mode; thus an increase in DIC over time will in both cases be indicated by a positive $\Delta$ DIC value. The $\Delta$ DIC values calculated this way are shown in Fig. 3.

The accuracy of the $\triangle \mathrm{DIC}$ values depends on the accuracy and precision of the DIC measurements and the predictor variables that vary from cruise to cruise. However, since all cruises have been subjected to bias adjustment (see Section 2.1) it can be assumed that the accuracy is within the limits discussed by Tanhua et al. (2010) and Olsen et al. (2016) for all cruises. Considering the best estimate of accuracy for DIC measurements being about $4 \mu \mathrm{mol} \mathrm{kg}{ }^{-1}$, the limit to the accuracy of the eMLR method for detecting decadal change will be approximately $6 \mu \mathrm{mol} \mathrm{kg}{ }^{-1}$ (by error propagation of the accuracy of the DIC measurements for the two cruises in consideration). In addition to biases, random uncertainty will add uncertainty to the $\triangle$ DIC estimates; see for instance the supporting materials in Tanhua et al. (2007). When using a number of cruises, all with potentially different uncertainties (and possibly biases), it is clear that changes in DIC $<6 \mu \mathrm{mol} \mathrm{kg}{ }^{-1}$ have to be considered as uncertain. For this study this means that most of the predicted changes below about $1000 \mathrm{~m}$ water depth are below the accuracy of the method, and should be treated as uncertain.

The so calculated change in DIC was used to calculate the storage rate of $\mathrm{C}_{\text {ant }}$ (i.e. the change in inferred $\mathrm{C}_{\text {ant }}$ concentration in units of $\mu \mathrm{mol} \mathrm{kg} \mathrm{yr}^{-1}$ ) to make the cruises comparable. Similar to the reasoning above we regard the significance or "detection limit" of $\mathrm{C}_{\text {ant }}$ storage

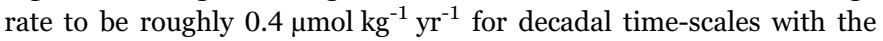
eMLR method.

\section{Results}

\subsection{Overview}

Sections along $10^{\circ} \mathrm{E}$ for potential density, salinity, potential temperature, DIC, alkalinity and oxygen (DO) as observed during the 2012 ANT-XXVIII/3 cruise are shown in Figs. 4 and 5. Close to the surface, DIC is relatively low but it increases from north to south from < $2100 \mu \mathrm{mol} \mathrm{kg}{ }^{-1}$ at $44-45^{\circ} \mathrm{S}$ to $>2140 \mu \mathrm{mol} \mathrm{kg}{ }^{-1}$ at $53^{\circ} \mathrm{S}$. In contrast, dissolved oxygen is relatively high at the surface and in the surface mixed layer, and also increases to the south. The dominant factor for the meridional increase of both DIC and DO is a concomitant temperature decrease, which enhances the solubility of the gases, but also biological activity can play a role. At the SAF, and to a lesser extent at the other fronts, the spatial gradients of DO and DIC are enhanced. At a position close to the APF, isolines which occur in the surface layer and upper pycnocline in the south are deepening going north. This illustrates the formation - or remnants of formation if AAIW had been formed at other locations in the ACC - of AAIW between the APF and the SAF. The AAIW reaches depths of about 1000-1200 $\mathrm{m}$ at the northern boundary of our section and is characterized by salinities below 34.3 (Fig. 4) which corresponds to densities between $27.0<\sigma_{\Theta}<$ 27.3 in the interior ocean although this is different for the mixed layer that is warmed up during the summer. AAIW is characterized by relatively high DO and low DIC concentrations. The characteristics of the waters in the upper 500-800 m north of the SAF suggest the presence of SAMW. Underneath the AAIW, a DIC maximum and oxygen minimum is observed at about $1500 \mathrm{~m}$ north of the SAF; it shoals toward the south and is the core of the UCDW. Right below the 

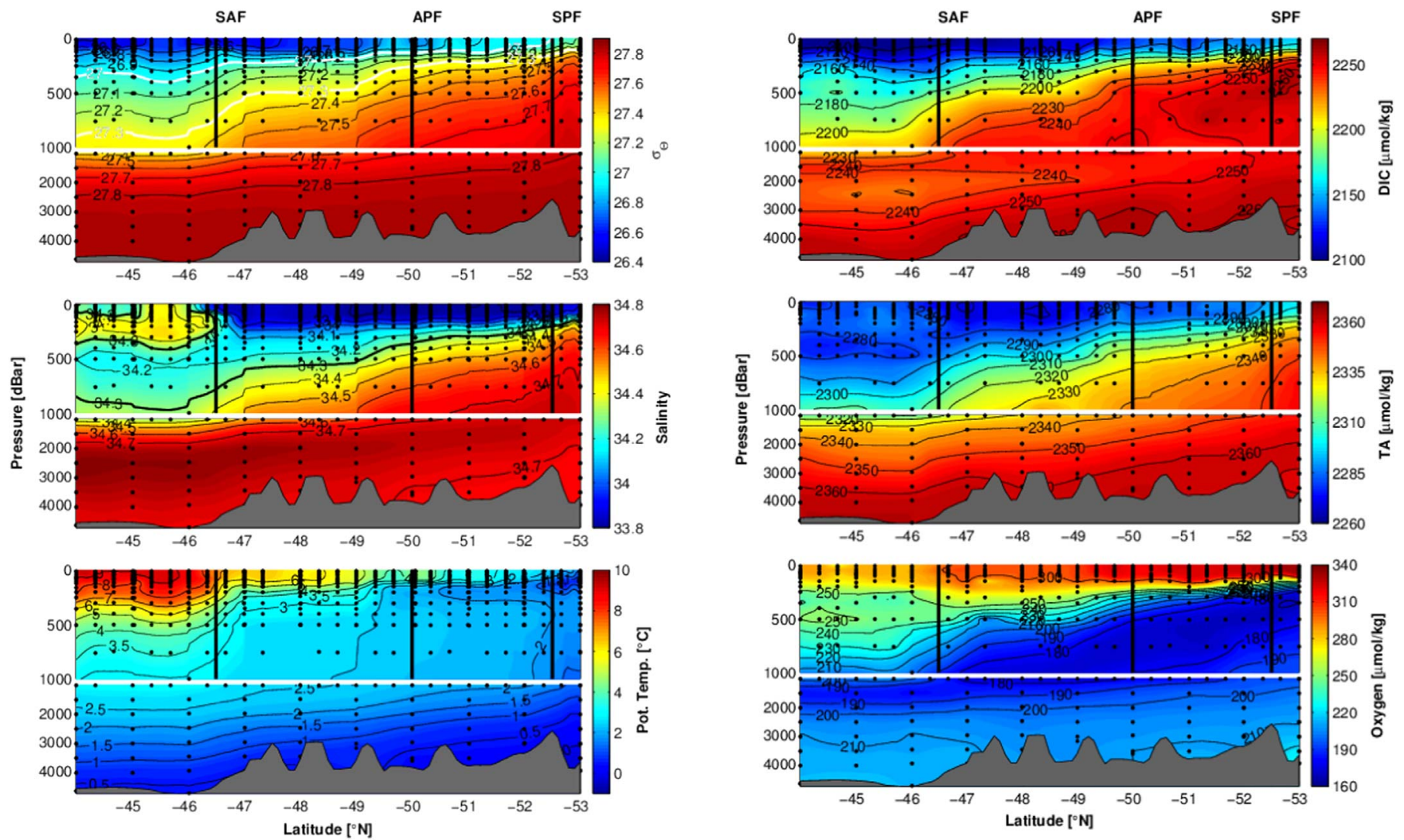

Fig. 4. Sections of: (a) potential density $\left(\sigma_{\Theta}\right.$ in $\mathrm{kg} \mathrm{m}^{-3}$ ), (b) salinity and (c) potential temperature along $10^{\circ} \mathrm{E}$ during cruise ANT.XXVIII/3 in 2012. The potential density isolines of 27.0 and 27.3, as well as the salinity isoline of 34.3 are highlighted in panels a and $\mathrm{b}$, delineating the extent of AAIW.

UCDW the LCDW can be found. This is characterized by increasing oxygen concentrations with depth. One of the source water masses of the LCDW is the NADW: north of about $49^{\circ} \mathrm{S}$ a remnant core of NADW is still recognizable in the LCDW by a DIC minimum centered at about $2500 \mathrm{~m}$. Also this core of minimum DIC shoals toward the south. In the southern part of the section, the influence of the waters from the south, i.e., the Weddell Gyre and Weddell-Scotia Confluence, is seen in the very high DIC and low DO in the upper $1000 \mathrm{~m}$, i.e., in the range of the UCDW. Waters in the bottom layer have relatively high DIC and high DO.

\subsection{Ventilation and recent changes}

The 2012 data set contains CFC-12 and $\mathrm{SF}_{6}$ measurements of a meridional section along $10^{\circ} \mathrm{E}$ between $44-53^{\circ} \mathrm{S}$ as recently discussed by Stöven et al. (2015). The distribution patterns of CFC-12 and $\mathrm{SF}_{6}$ are similar and generally close to saturation in the mixed layer and with decreasing concentrations with increasing depth. Whereas CFC-12 could be detected throughout the water column, the $\mathrm{SF}_{6}$ concentration is below the detection limit $\left(0.1 \mathrm{fmol} \mathrm{kg}{ }^{-1}\right)$ in most of the water masses below 1000-1500 m depth (Fig. 6). An exception to this is found at the southernmost station at $53^{\circ} \mathrm{S}$ where elevated $\mathrm{SF}_{6}$ concentrations are found close to the bottom. This implies that the use of $\mathrm{SF}_{6}$ for quantification of ventilation in the water column is generally restricted to the upper ocean layers but that the CFC-12 data provides a fulldepth tracer distribution pattern in the Southern Ocean. However, the use of $\mathrm{CFC}-12$ in recent years is ambiguous due to the recent decrease of the CFC-12 concentration in the atmosphere so that the $\mathrm{SF}_{6}$ data are more useful for recently ventilated water masses.

Due to large-scale upwelling of deeper water masses in the Antarctic Divergence zone, the mid-depth tracer gradient increases

Fig. 5. Sections of: (a) dissolved inorganic carbon, (b) total alkalinity, and (c) dissolved oxygen along $10^{\circ} \mathrm{E}$ during cruise ANT-XXVIII/3 in 2012.

towards the south. The distribution of the CFC-12 concentration in the deep water masses is characterized by a minimum with partial pressures below 30 ppt between $2000 \mathrm{~m}$ and $3700 \mathrm{~m}$ north of $46^{\circ} \mathrm{S}$, which is associated with LCDW Influenced by the North Atlantic Deep Water (NADW). The minimum core shoals towards the south while the partial pressure increases to $40 \mathrm{ppt}$ due to continuous mixing with surrounding waters with higher CFC-12. The minimum becomes more ambiguous south of $51^{\circ} \mathrm{S}$ with partial pressures between $40-50$ ppt as the core of LCDW erodes. The core of the LCDW is among the oldest waters in this region. The CFC-12 partial pressure in the deep water below the minimum increases with increasing latitude, from $40 \mathrm{ppt}$ at $44^{\circ} \mathrm{S}$ to $65 \mathrm{ppt}$ at the southernmost station at $53^{\circ} \mathrm{S}$, associated with recently ventilated AABW. This is consistent with $\mathrm{SF}_{6}$ concentrations above the detection limit at the southernmost station, with partial pressures between 0.7 and $1 \mathrm{ppt}$ in the AABW.

Fig. $6 \mathrm{c}$ and $\mathrm{d}$ shows the results of the time lag analysis, i.e. the tracer age differences between modern $\mathrm{SF}_{6}$ data (ANT-XXVIII/3, 2012) and historic CFC-12 data (ANT-XV/4 or the SWEDARP expedition, both from 1998). The vertical solid lines highlight the positions of the fronts of the Southern Ocean in 2012 (Strass et al., 2016). The solid white contour lines correspond to the densities that bound the AAIW. Note that the data was obtained during summer time in which no formation of AAIW takes place and the outcrop of the density and salinity layers are located further south. $\mathrm{SF}_{6}$ data below the detection limit of $0.1 \mathrm{fmol} \mathrm{kg}^{-1}$ are indicated by the white patch, similar to that in Fig. 6a. The difference in tracer age was calculated by subtracting the tracer age $\left(\mathrm{SF}_{6}\right.$-age minus $\mathrm{CFC}-12$ age, i.e. modern age minus historic age; positive values indicate reduced ventilation or higher age) gridded for each of the cruises on an identical grid; note that the ANT-XV/4 (1998) cruise has no CFC-12 data north of $50^{\circ} \mathrm{S}$.

Fig. 6d shows positive tracer age differences of up to 5 years between $47-51^{\circ} \mathrm{S}$ below $500 \mathrm{~m}$ depth, which is also indicated at $50{ }^{\circ} \mathrm{S}-$ $51^{\circ} \mathrm{S}$ (the northern end of the available data) in Fig. 6c. This is 

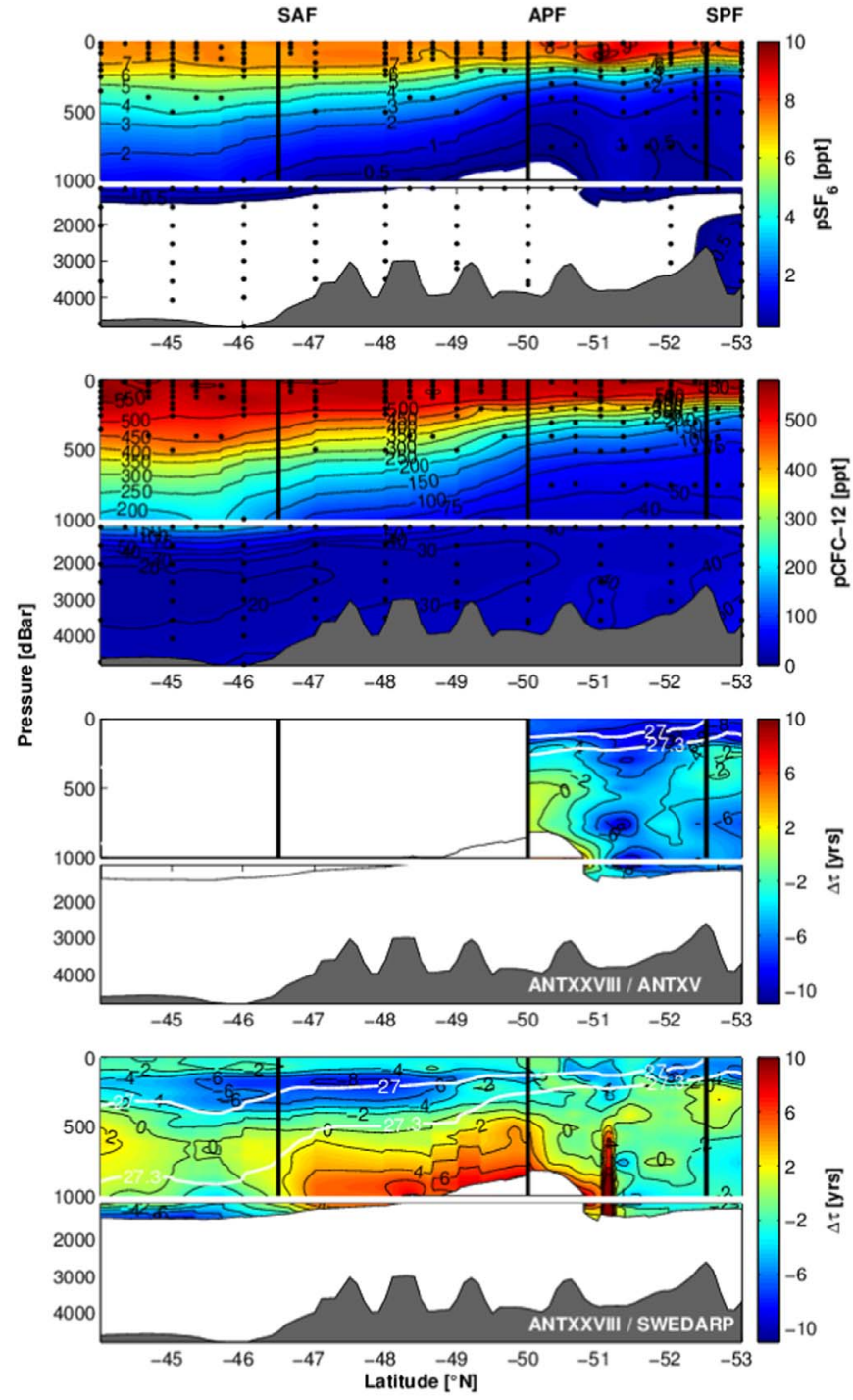

Fig. 6. Sections of transient tracer observations along $10^{\circ} \mathrm{E}$ : (a) the $\mathrm{SF}_{6}$ partial pressure, (b) the CFC-12 partial pressure. The difference in tracer age between the 2012 ANTXXVIII/3 cruise and (c) cruise 06AQ19980328 (ANT-XV/4), and d) the SWEDARP cruise from 1997/98; positive values indicate that the tracer age has increased, i.e. a slow-down of ventilation.

indicative of a slow-down in ventilation in the Upper Circumpolar Deep Water (UCDW) located below the salinity minimum of AAIW, and can be explained by enhanced upwelling of old deep water masses from below. In contrast, the intermediate water masses below $800 \mathrm{~m}$ south of $51{ }^{\circ} \mathrm{S}$ and the intermediate water masses below $1100 \mathrm{~m}$ north of $46^{\circ} \mathrm{S}$ show a slight speed-up in ventilation as indicated by tracer age differences $<-6$ years. For the waters south of $51^{\circ} S$ the tracer couple of the ANT-XXVIII/3 and ANT-XV/4 cruises indicates a larger increase in ventilation (about -6 years) than the tracer couple ANT-XXVIII/3 and SWEDARP, the latter results being within the uncertainty interval of \pm 3 years of the method, leaving the results from these two pairs of observations inconclusive. The inconsistency of the results may be caused by the different locations of the two data sets from 1998 but also by the fact that the region south of $51^{\circ} \mathrm{S}$ is a frontal region with several sub-fronts in which water mass variability through circulation features are common. The remaining water in the depth range of 400-1000 m (south of $51^{\circ} \mathrm{S}$ and in the AAIW layer north of the SAF) shows no significant change in ventilation. The upper $400 \mathrm{~m}$ between $46^{\circ}$ and $49^{\circ} \mathrm{S}$ is characterized by tracer age differences between -2 and -8 years, i.e. increased ventilation in the SAMW and upper part of the AAIW. Note that there is no boundary effect at the SAF whereas the water masses south of the APF exhibit a more unsteady distribution of tracer age differences. The high "spike" in age differences in Fig. 6d at $\sim 51^{\circ} \mathrm{S}$ may reflect uncertainty in the low-concentration measurements of transient tracers or real variability such as eddies or fronts.

\section{3. $C_{\text {ant }}$ storage rates}

The $\mathrm{C}_{\mathrm{ant}}$ storage rates for the seven cruises are shown in Fig. 7 (the eighth cruise is our reference cruise which has, by definition, zero change); areas with storage rates below detection limit are white. Note that although we calculate the change in DIC, we infer that this represents the change in $\mathrm{C}_{\mathrm{ant}}$. There is some variability between the storage rates for the different years. This is due to a combination of natural variability in circulation and ventilation (and thus in $\mathrm{C}_{\mathrm{ant}}$ storage rate), an effect of varying sampling density and zonal extent of sampling, and of uncertainty of the eMLR calculations. In particular, some of the variability might be due to different eMLR formulations used; during the 1998 cruise alkalinity was not measured and no nitrate is available for the 2005 cruise so the MLR formulations for these cruises were different from the others. Possibly the relatively high uptake rates for the 1990-1998 and 1990-2005 periods are to some extent associated with bias in the eMLR - on the other hand, though restricted to a smaller area, the uptake rate during the period 19841990 is also much higher than in later years. The storage rates shown in Fig. 7 represent time-integrated means of the storage rate for the time between 1990 and the year of the analyzed cruise, so that lower frequently variability can only be detected by comparing storage rates of cruises close in time.

For all cruises there is a significant storage rate in the upper water column (Fig. 7). Note that the mixed layer is excluded from this analysis due to the strong seasonality in this layer which the eMLR analysis might not be able to resolve. This is particularly visible within the SAMW in the upper water column in the northern part of the section; the $\mathrm{C}_{\text {ant }}$ storage rate for SAMW is high for the period until 2005, whereas the period 2008-2012 has similar storage rates for the SAMW north of the SAF compared to the 1990-2005 rates indicating little additional storage after 2005, but higher storage rates for the less saline waters south of the SAF. Note that low $\mathrm{C}_{\text {ant }}$ storage rates for the 1973-1990 period are expected due to the lower atmospheric forcing in the earlier years. Significant $C_{a n t}$ storage rate is also observed in the AAIW (between the white contour lines in Fig. 7) with the exception of the 1984-1990 period where significant storage is only seen in the upper part of the AAIW. Within the AAIW, the $\mathrm{C}_{\mathrm{ant}}$ storage rate decreases with depth, and also (since the age also increases with depth) with age. The DIC storage rate in the AAIW is significantly smaller before 1990 (note that the density isolines in Fig. 7 marking the extent of the AAIW are for the 1990 reference cruise, but there is large similarity to the extent of the relevant density isolines for the 2012 cruise). The highest $\mathrm{C}_{\mathrm{ant}}$ storage rates in the AAIW are found for the 1990-1998 (although this estimate is likely biased high due to a MLR formulation without alkalinity, particularly in the deep parts of the section) and 1990-2005 periods, lower rates for the 1990-2008 and 1990-2010 periods, and an increase for the 1990-2012 period again; the lowest rates are found for the 1984-1990 period and low to intermediate $\mathrm{C}_{\mathrm{ant}}$ storage rates for the 1973-1990 period. Summarizing the above we find lower $\mathrm{C}_{\text {ant }}$ storage rates during the 1980 s, high rates during the 1990s/early 2000s, and again slightly lower rates during the most recent time. For the deeper layers below the AAIW, i.e. in the CDW, NADW and AABW, all periods, with the exception of the 1990-1998 period, show storage rates below the detection limit of the method. However, all periods after 1990 show a non-zero positive change in DIC for the deep waters, indicating accumulation of $\mathrm{C}_{\mathrm{ant}}$ also in the deep waters although below our detection limit (not shown).

We also integrate the $\mathrm{C}_{\mathrm{ant}}$ storage rate over the water column as this is a useful quantity for comparison with other ocean areas (Fig. 8). The 
(A)
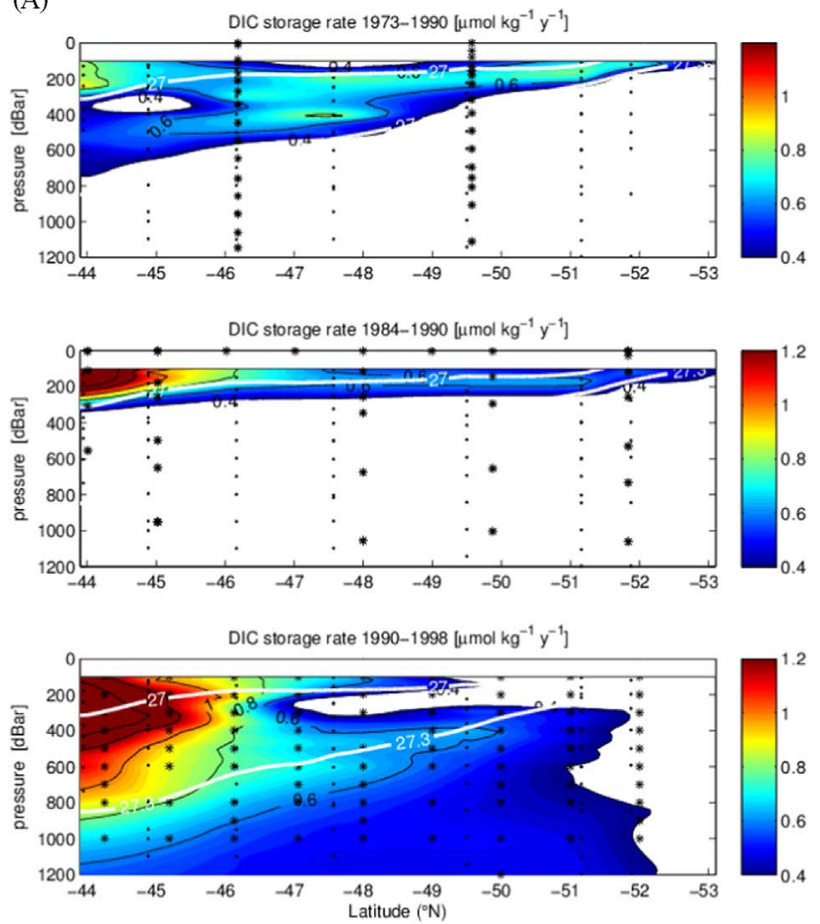

(B)
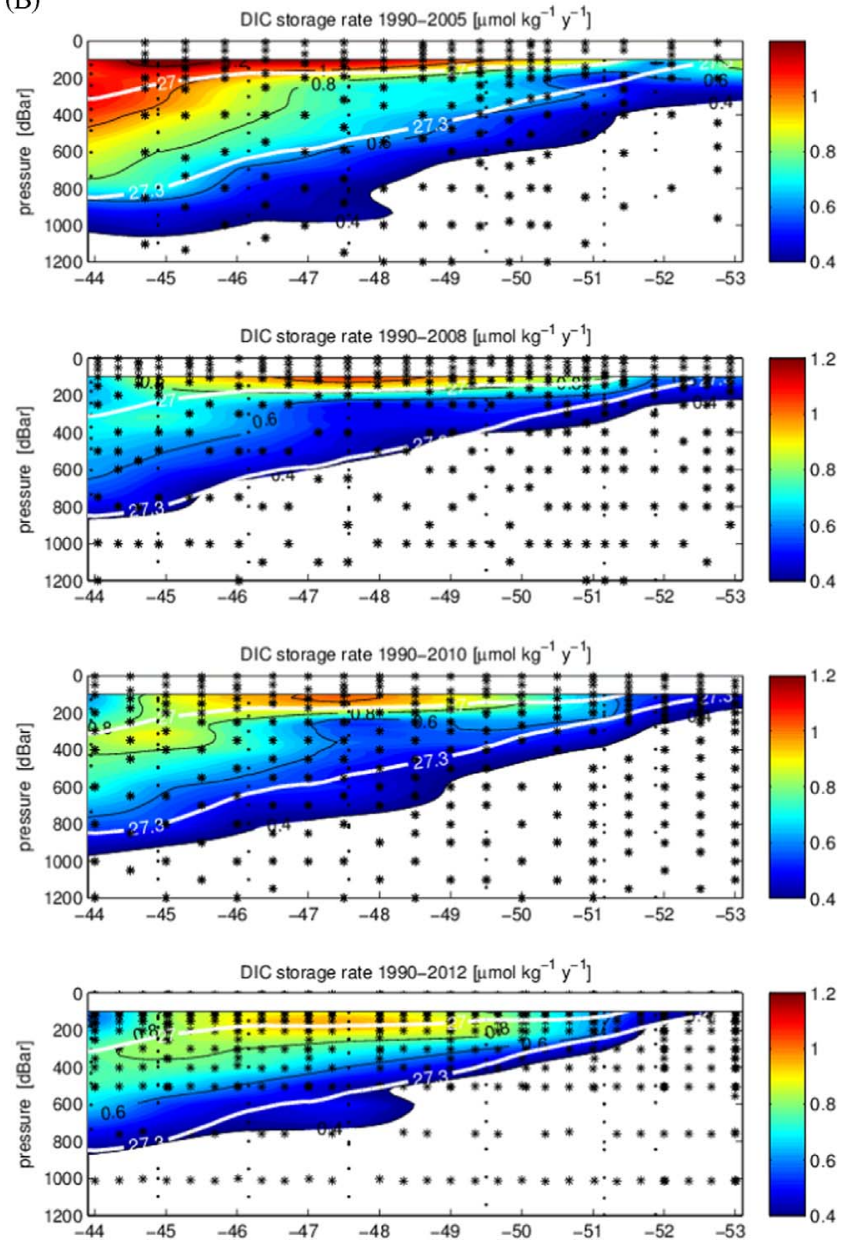

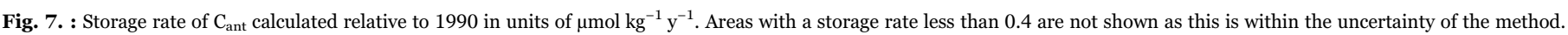

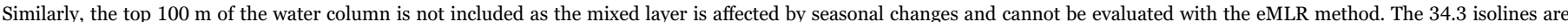

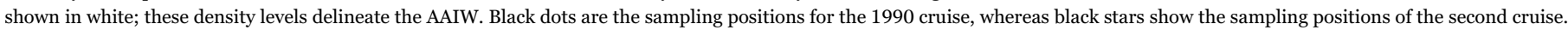

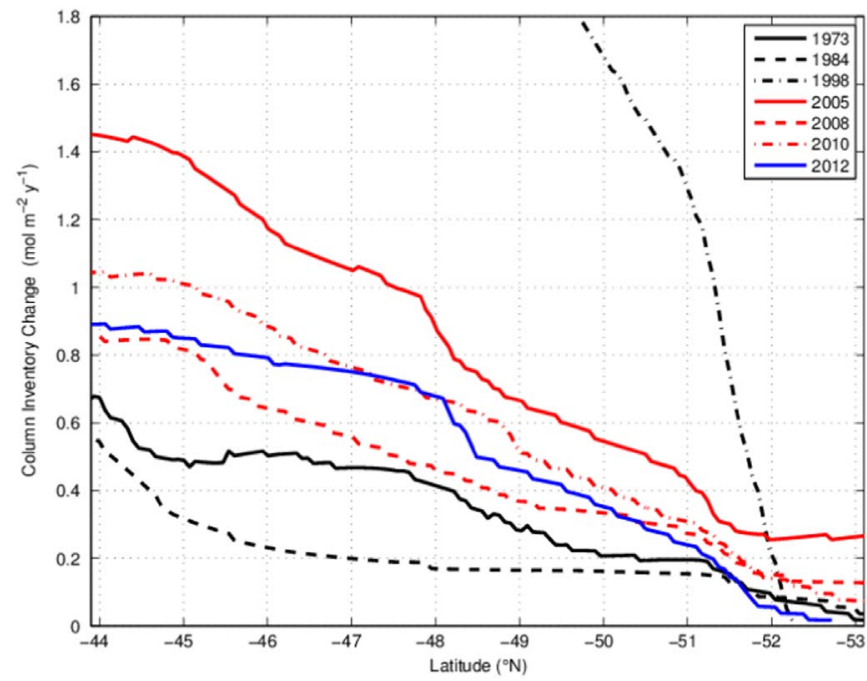

Fig. 8. Integrated column inventories of $C_{a n t}$ storage rates between 1990 and the year stated in the legend as a function of latitude along the $10^{\circ} \mathrm{E}$ section. Only data from below 100 depth and with DIC storage rates $>0.4 \mu \mathrm{mol} \mathrm{kg}^{-1} \mathrm{y}^{-1}$ are considered for these calculations.

global averaged column storage rate of $\mathrm{C}_{\mathrm{ant}}$ is in the order of $0.55 \mathrm{~mol} \mathrm{~m}^{-2} \mathrm{y}^{-1}$, although this number is obviously transient with a general increase over time to be expected (Sabine et al., 2008), but it provides a benchmark against which the column inventory in the Atlantic sector of the Southern Ocean can be compared. For this calculation we only considered storage rates in excess of the detection limit of $0.4 \mu \mathrm{mol} \mathrm{kg}^{-1} \mathrm{y}^{-1}$ and the water column below the mixed layer (100 $\mathrm{m}$ for this purpose). This means that the true column storage rate is higher by, at least, approximately 0.07 and $0.08 \mathrm{~mol} \mathrm{~m}^{-2} \mathrm{y}^{-1}$ for the 1970s and the 2010s, respectively (based on well-known carbonate chemistry, assuming equilibration of $\mathrm{C}_{\mathrm{ant}}$ in the mixed layer), since we expect an increase over time in the mixed layer. Additionally, there is also a contribution to storage below the AAIW layer (based on the observed CFC-12 concentration) that is not accounted for in the estimates in Fig. 8. The figure clearly shows the trend to a higher storage rate towards the north, along the flow path of the AAIW, for all cruises but the 1984 one. Significant variability in the storage rate for the different cruises is evident, with the 1998 and 2005 cruises as positive outliers; the 1998 cruise is probably biased high due to using an MLR formulation without alkalinity, and the 2005 cruise could be biased due a different MLR formulation and/or calculated DIC rather than measured, and both are disregarded in this discussion.

In an attempt to quantify the storage rates over a variety of time periods we calculated the difference in storage rate for all possible combinations of repeats. This was performed by first calculating the integrated amount stored for each section relative to 1990 (see Fig. 8), then subtracting the amount between two sections and calculate the storage rate (by dividing by the time between repeats). The 1998 results are discarded due to biased results as discussed above. The results of this exercise are shown in a Table 3 . The possible bias and uncertainty 
Table 3

Storage rate for all possible combinations of repeat lines (in $\mathrm{kmol} \mathrm{y}^{-1} \mathrm{~m}^{-1}$ ) integrated over the full length of the section (i.e. storage rate over the whole section assuming section being one meter wide and that storage rates below $0.4 \mu \mathrm{mol} \mathrm{kg}^{-1} \mathrm{y}^{-1}$ are below detection limit and are neglected, see Fig. 8). Numbers in parentheses are deemed less reliable due to the short time between repeats.

\begin{tabular}{|c|c|c|c|c|c|c|c|}
\hline 2012 & & & & & & & 0 \\
\hline 2010 & & & & & & 0 & $(-722)$ \\
\hline 2008 & & & & & 0 & (2469) & (873) \\
\hline 2005 & & & & 0 & $(-2920)$ & $(-764)$ & $(-752)$ \\
\hline 1990 & & & 0 & 358 & 699 & 876 & 730 \\
\hline 1984 & & 0 & 440 & 1142 & 634 & 775 & 668 \\
\hline \multirow[t]{2}{*}{1973} & 0 & 613 & 552 & 960 & 628 & 727 & 653 \\
\hline & 1973 & 1984 & 1990 & 2005 & 2008 & 2010 & 2012 \\
\hline
\end{tabular}

of the eMLR method, as discussed above, is expressed in the anomalous storage rates for cruises occupied only a few years apart (in parentheses in Table 3). Similarly, storage rates against the 2005 repeat tend to be high/low, a further indication of the MLR results from this cruise being biased high. The periods 1973-1990 and 19841990 have, as expected, the lowest storage rate and the periods from 1990 to 2008, 2010 and 2012 all have comparable storage rates intermediate between the 1984-1990 and 1990-2005 rates.

\section{Discussion}

We venture to compare trends in $\mathrm{C}_{\text {ant }}$ uptake at the surface interface of the Southern Ocean with those in subsurface water layers. It is important to realize that these two processes act on different time scales so that trends or variability in the surface layer uptake of $\mathrm{C}_{\text {ant }}$ will be expressed in the interior ocean in later years. Furthermore, temporal and spatial variability tends to be less pronounced in the interior ocean (as compared to the surface ocean) due to the integrating action of ocean mixing. The time lag from a surface perturbation to an interior ocean signal is directly linked to the rate of ventilation, for which the transient tracer concentration (or the inferred ventilation age) is a measure; see Fig. 6. This means that observed variability of ocean mixed layer uptake will be manifested years later in the interior ocean along the densities of AAIW, but that more rapid signal propagation can be expected for the SAMW which occurs above the AAIW.

The results from our time-lag analysis are compared to the Southern Ocean ventilation analysis by Waugh et al. (2013). In the latter study, predicted tracer concentrations from a steady state Inverse Gaussian Transit time Distribution (IG-TTD) model were compared to observed transient tracer fields from different repeat hydrography sections; differences between observed and predicted tracer concentrations then indicate changes in ventilation. Although Waugh et al. (2013) analyzed changes between 1989 and 2005/2006 (for the A16 section in the Atlantic sector at $\sim 20^{\circ} \mathrm{W}$ ) and our $\mathrm{CFC}-/ \mathrm{SF}_{6}$-based analysis covers the time-frame 1998-2012, both analyses indicate generally decreasing ventilation of the CDW and increase in ventilation for the lighter density SAMW waters. Also consistent with the analysis of Waugh et al. (2013) is that we do not see any conclusive trend in the AAIW water layer that is located between the CDW and the SAMW layers.

Based on the 7 repeat sections of the DIC storage rate (Fig. 7) it is possible to detect the changes and trends of storage rates in the different water masses. The most pronounced variability is observed in the SAMW, i.e., in the upper 500-700 m north of the SAF; in the period from 1973 to 2005 the rates are very high (although slightly lower for the 1973-1990 period due to the moderate increase rates of atmospheric $\mathrm{CO}_{2}$ ). After 2005 the DIC storage rates are relatively low in the core of SAMW north of the SAF, but high in the upper layer waters south of the SAF; this water is within the density layer of SAMW but has low salinity values typical of AAIW. This appears to represent a change of trend somewhere between 2005 and 2008, where the situation in 2005 may be a transition state, with both high rates in the SAMW core and high rates in the upper layers south of the SAF. In the early period until about 2005 the ventilation accompanying the formation of SAMW must have been strong and the recently ventilated waters, with high anthropogenic $\mathrm{CO}_{2}$ content, were advected south. $\mathrm{C}_{\mathrm{ant}}$ storage. During this period, the Southern Annular Mode was moving into its more positive phase, increasing the strength of the westerly winds and shifting the wind fields southward, leading to elevated upwelling of the deep waters of the ACC. This must also have led to a shift of the outcropping of deep waters to the south. The new surface waters relatively poor in $\mathrm{C}_{\mathrm{ant}}$ thus also shifted to the south. These new surface waters subsequently were able to take up (anthropogenic) $\mathrm{CO}_{2}$ from the atmosphere. The shift of the high $\mathrm{C}_{\mathrm{ant}}$ storage rates from north to south may thus be related to the shifting Southern Annular Mode. After the early 2000 s, the Southern Annular Mode did not show a trend anymore, consolidating the state of more southerly based ventilation through the AAIW.

In an influential study, the uptake of $\mathrm{CO}_{2}$ by the Southern Ocean was suggested to be dwindling due to elevated upwelling of $\mathrm{CO}_{2}-$ charged deep waters (e.g. Le Quéré et al., 2007;). Upwelling brings water with high DIC concentration, but low $\mathrm{C}_{\mathrm{ant}}$ concentration, to the surface where $\mathrm{CO}_{2}$ will then be outgassed to the atmosphere. At constant upwelling, the steady increase of $\mathrm{CO}_{2}$ in the atmosphere causes the magnitude of outgassing to get lower and lower; the difference between inferred pre-industrial outgassing and the lower contemporary outgassing is in fact uptake of $\mathrm{C}_{\text {ant }}$, namely a reduced sea-to-air flux of $\mathrm{CO}_{2}$ - this should be considered a smaller side effect.

The $\mathrm{C}_{\mathrm{ant}}$ storage rate was high in the SAMW during most of the period while the Southern Annular Mode was in its positive phase, which is counterintuitive as this Southern Annular Mode phase tends to decrease the $\mathrm{CO}_{2}$ uptake (Lenton and Matear, 2007). We think that the upwelling of $\mathrm{CO}_{2}$-rich but $\mathrm{C}_{\text {ant }}$-poor water occurs more to the south from where this $\mathrm{C}_{\mathrm{ant}}$-poor water moves northward with the enhanced Ekman transport on its way picking up anthropogenic $\mathrm{CO}_{2}$ from the atmosphere. By the time this water becomes part of the SAMW it will be rich in $\mathrm{C}_{\mathrm{ant}}$. Recently, it was suggested that the slowing down of the Southern Ocean anthropogenic $\mathrm{CO}_{2}$ uptake came to an end in about 2002 (e.g. Fay et al., 2014; Landschützer et al., 2014, 2015). This suggests that the elevated upwelling of deeper waters has become less important for dampening anthropogenic $\mathrm{CO}_{2}$ uptake in the Atlantic sector than before; weakening of the upwelling could cause uptake of $\mathrm{C}_{\text {ant }}$ by the subsurface waters, which is consistent with our observations of enhanced $\mathrm{C}_{\text {ant }}$ uptake for the period from 2005 onwards in the AAIW surface layer. Within the meridional overturning circulation of the Southern Ocean, one would expect consequences for the ventilation processes near the northern boundary of the ACC as well, i.e., a reduction of SAMW transport. This is again in line with our results, showing reduced $\mathrm{C}_{\mathrm{ant}}$ storage rates in the SAMW core north of the SAF for the period after 2005. There is a general increasing trend in the $\mathrm{C}_{\mathrm{ant}}$ storage rate in the AAIW during the recent times, in line with the increasing atmospheric $\mathrm{CO}_{2}$ concentration.

The column storage rate of $\mathrm{C}_{\mathrm{ant}}$ can be compared to those from the Green's function method estimates of integrated $\mathrm{C}_{\mathrm{ant}}$ storage rates based on transient tracer data, that clearly shows the meridional gradient in storage rate across the ACC (Khatiwala et al., 2013) but with our estimates being slightly higher. A comparable gradient across the ACC was found for a similar calculations in the Pacific Ocean where Sabine et al. (2008) found up to $0.75 \mathrm{~mol} \mathrm{~m}^{-2} \mathrm{y}^{-1}$ along $150^{\circ} \mathrm{W}$ at about the same latitudes. In addition to temporal trends in the integrated storage rate, variability that can be linked to uncertainty in data and to the eMLR method is evident.

The shape of the integrated $\mathrm{C}_{\mathrm{ant}}$ storage rate over the water column for the cruise in 1984 is different from those of the other ones (Fig. 8). Over most of the latitude band the storage is constant in 1984 and only at about $46^{\circ} \mathrm{S}$ it starts to increase, whereas the other cruises exhibit increases near the Polar Front near $50-51^{\circ} \mathrm{S}$. This suggests a different 
uptake mechanism in 1984 with not much activity near the Polar Front. We may speculate that a shift in wind field and upwelling has started somewhere after 1984, possibly associated with the Southern Annular Mode in that time clearly moving into the more positive phase (see Fig. 4 in Johnston and Gabric, 2011).

\section{Conclusions}

Data from eight cruises to the Atlantic sector of the Southern Ocean (44-53 ${ }^{\circ}$ S) between 1973 and 2012 reveal substantial uptake of anthropogenic carbon in the upper water column (roughly bound by the 27.3 potential density anomaly surface, i.e. the lower limit of the Antarctic Intermediate Water) during this time period. The storage rate of $\mathrm{C}_{\mathrm{ant}}$ over this entire period is roughly what would be expected based on known atmospheric forcing. Transient tracer (CFC-12 and $\mathrm{SF}_{6}$ ) observations in 1998 and 2012 indicate the presence of anthropogenic carbon beyond the surface layers, through the whole water column based on the presence of CFC-12, although at too small concentrations to be able to reliable quantify it with the eMLR method used for our analysis. We observe moderate and steady uptake of $\mathrm{C}_{\text {ant }}$ in the AAIW layer throughout the time period, which confirms AAIW to be a dominant conduit for $\mathrm{C}_{\mathrm{ant}}$ transport into the interior ocean. In the near-surface layer consisting of seasonally warmed AAIW between 46 and $50{ }^{\circ} \mathrm{S}$ we observed a trend of increasing $\mathrm{C}_{\mathrm{ant}}$ storage rates with time. In Subantarctic Mode Water, on the other hand, temporal variability of $\mathrm{C}_{\mathrm{ant}}$ storage rates were observed with high rates up to about 2005 and somewhat lower rates in more recent times. A comparison of CFC-12 data from 1998 and $\mathrm{SF}_{6}$ data from 2012 suggests a significant speed-up of ventilation in the summer warmed upper part of AAIW between 1998 and 2012, which is consistent with the observed recent high storage rate of $\mathrm{C}_{\text {ant }}$ in that layer. The observed temporal variability in the interior ocean seems at a first glance to be out of phase with observed surface ocean $C_{a n t}$ fluxes, but this can be explained by the time delay for the surface ocean signal to manifest itself in the interior ocean. Based on the recently reported reinvigoration of the Southern Ocean $\mathrm{CO}_{2}$ sink in surface waters, it is expected that a signal of enhanced storage of $\mathrm{C}_{\mathrm{ant}}$ should be observable in the interior ocean during the next years to come.

\section{Acknowledgements}

The authors thank the captains and crews on the numerous research vessels that were involved in collecting the data used for this study in the Southern Ocean. This work was supported by the Deutsche Forschungsgemeinschaft (DFG) in the framework of the "Antarctic Research with comparative investigations in Arctic ice areas" priority program: Carbon and transient tracer dynamics: A bi-polar view on Southern Ocean eddies and the changing Arctic Ocean (TA 317/5, HO 4680/1). Partial support to T. Tanhua and M. Hoppema was received from EU FP7 project CARBOCHANGE (grant agreement no. 264879). J. Hauck was supported by the Helmholtz PostDoc Programme (Initiative and Networking Fund of the Helmholtz Association) and by the German project Biological Impacts of Ocean ACIDification (BIOACID), funded by the Federal Ministry of Education and Research (BMBF, FKZ 03F0608B).

\section{References}

Abernathey, R.P., Cerovecki, I., Holland, P.R., Newsom, E., Mazloff, M., Talley, L.D., 2016. Water-mass transformation by sea ice in the upper branch of the Southern Ocean overturning. Nat. Geosci.. http://dx.doi.org/10.1038/ngeo2749.

Álvarez, M., Tanhua, T., Brix, H., Lo Monaco, C., Metzl, N., McDonagh, E.L., Bryden, H.L., 2011. Decadal biogeochemical changes in the subtropical Indian Ocean associated with Subantarctic Mode Water. J. Geophys. Res. 116, C09016. http:// dx.doi.org/10.1029/2010jc006475.

Bainbridge, A.E., 1981. GEOSECS Atlantic Expedition, vol. 1. Hydrographic Data 19721973, IDOE/ NSF, 12, 1,

Bullister, J.L., Wisegarver, D.P., Menzia, F.A., 2002. The solubility of sulfur hexafluoride in water and seawater, Deep-Sea Res. I 49, 175-187.

Bullister, J.L., 2015. Atmospheric Histories (1765-2015) for CFC-11, CFC-12, CFC-113, $\mathrm{CCl}_{4}, \mathrm{SF}_{6}$ and $\mathrm{N}_{2} \mathrm{O}$, Carbon Dioxide Information Center.

Caldeira, K., Duffy, P.B., 2000. The role of the southern ocean in uptake and storage of anthropogenic carbon dioxide. Science 287, 620-622. http://dx.doi.org/10.1126/ science.287.5453.620.

Chipman, D.W., Takahashi, T., Sutherland, S.C., 1986. Carbon chemistry of the South Atlantic Ocean and the Weddell Sea: The results of the Atlantic Long Lines (AJAX) Expeditions, October, 1983-February, 1985. LDGO.

Chipman, D.W., Takahashi, T., Breger, D., Sutherland, S.C., 1994 Carbon Dioxide, Hydrographic, and Chemical Data Obtained During the R/V Meteor Cruise 11/5 in the South Atlantic and Northern Weddell Sea Areas (WOCE sections A-12 and A-21). Carbon Dioxide Information Analysis Center, Oak Ridge National Laboratory, U.S. Department of Energy, Oak Ridge, Tennessee.

Fay, A.R., McKinley, G.A., Lovenduski, N.S., 2014. Southern Ocean carbon trends: sensitivity to methods. Geophys. Res. Lett. 41, 2014GL061324. http://dx.doi.org/ 10.1002/2014GL061324.

Fine, R.A., 2011. Observations of CFCs and SF(6) as ocean tracers. Annu. Rev. Mar. Sci. 3 (3), 173-195. http://dx.doi.org/10.1146/annurev.marine.010908.163933.

Friis, K., Körtzinger, A., Pätsch, J., Wallace, D.W.R., 2005. On the temporal increase of anthropogenic $\mathrm{CO}_{2}$ in the subpolar North Atlantic. Deep-Sea Res. I 52, 681-698. http://dx.doi.org/10.1016/j.dsr.2004.11.017.

Frölicher, T.L., Sarmiento, J.L., Paynter, D.J., Dunne, J.P., Krasting, J.P., Winton, M., 2015. Dominance of the Southern Ocean in Anthropogenic Carbon and Heat Uptake in CMIP5 Models. J Clim. 28, 862-886. http://dx.doi.org/10.1175/JCLI-D-1400117.1 .

Gladyshev, S., Arhan, M., Sokov, A., Speich, S., 2008. A hydrographic section from South Africa to the southern limit of the Antarctic Circumpolar Current at the Greenwich Meridian. Deep Sea Res. Part I: Ocean. Res. Pap. 55, 1284-1303. http://dx.doi.org/ 10.1016/j.dsr.2008.05.009.

González-Dávila, M., Santana-Casiano, J.M., Fine, R.A., Happell, J., Delille, B., Speich, S., 2011. Carbonate system in the water masses of the Southeast Atlantic sector of the Southern Ocean during February and March 2008. Biogeosciences 8, 1401-1413 . http://dx.doi.org/10.5194/bg-8-1401-2011.

Goodkin, N.F., Levine, N.M., Doney, S.C., Wanninkhof, R., 2011. Impacts of temporal $\mathrm{CO}_{2}$ and climate trends on the detection of ocean anthropogenic $\mathrm{CO} 2$ accumulation. Glob. Biogeochem. Cycle 25, GB3023. http://dx.doi.org/10.1029/2010GB004009.

Gordon, A.L., Huber, B.A., 1990. Southern ocean winter mixed layer. J. Geophys. Res.: Ocean 95, 11655-11672. http://dx.doi.org/10.1029/JC095iC07p11655.

Gruber, N., Gloor, M., Mikaloff Fletcher, S.E., Doney, C.S., Dutkiewicz, S., Follows, M., Greber, M., Jacobson, A.R., Joos, F., Lindsay, K., Menemenlis, D., Mouchet, A., Müller, S.A., Sarmiento, J., Takahashi, K., 2009. Ocean sources, sinks, and transport of atmospheric $\mathrm{CO}_{2}$, global Biogeochem. Cycles 23, GB1005.

Hall, T.M., Plumb, R.A., 1994. Age as a diagnostic of stratospheric transport,. J. Geophys. Res.: Atmosph. 99, 1059-1070. http://dx.doi.org/10.1029/93JD03192.

Hauck, J., Völker, C., 2015. Rising atmospheric $\mathrm{CO}_{2}$ leads to large impact of biology on Southern Ocean $\mathrm{CO}_{2}$ uptake via changes of the Revelle factor. Geophys. Res. Lett. 42, 2015GL063070. http://dx.doi.org/10.1002/2015GL063070.

Henson, S.A., Sanders, R., Madsen, E., 2012. Global patterns in efficiency of particulate organic carbon export and transfer to the deep ocean. Glob. Biogeochem. Cycle 26, GB1028. http://dx.doi.org/10.1029/2011GB004099.

Hoppe, C.J.M., Klaas, C., Ossebaar, S., Soppa, M.A., Cheah, W., Laglera, L.M., SantosEcheandia, J., Rost, B., Wolf-Gladrow, D.A., Bracher, A., Hoppema, M., Strass, V., Trimborn, S., 2016. Controls of primary production in two phytoplankton blooms in the Antarctic Circumpolar. Curr., Deep Sea Res. Part II: Top. Stud. Oceanogr.. http://dx.doi.org/10.1016/j.dsr2.2015.10.005.

Hoppema, M., Klatt, O., Roether, W., Fahrbach, E., Bulsiewicz, K., Rodehacke, C., Rohardt, G., 2001. Prominent renewal of Weddell Sea Deep Water from a remote source. J. Mar. Res. 59, 257-279. http://dx.doi.org/10.1357/ 002224001762882655

Hoppema, M., 2004. Weddell Sea is a globally significant coontributor to deep-sea sequestration of natural carbon dioxide. Deep Sea Res. - II 51, 1169-1177.

Huhn, O., Rhein, M., Hoppema, M., van Heuven, S., 2013. Decline of deep and bottom water ventilation and slowing down of anthropogenic carbon storage in the Weddell Sea, 1984-2011. Deep Sea Res. Part I: Oceanogr. Res. Pap. 76, 66-84. http:// dx.doi.org/10.1016/j.dsr.2013.01.005.

Johnston, B.M., Gabric, A.J., 2011. Interannual variability in estimated biological productivity in the Australian sector of the Southern Ocean in 1997-2007. Tellus B 63, 266-286. http://dx.doi.org/10.1111/j.1600-0889.2011.00526.x.

Jones, E.M., Hoppema, M., Strass, V., Hauck, J., Salt, L., Ossebaar, S., Klaas, C., van Heuven, S.M.A.C., Wolf-Gladrow, D., Stöven, T., de Baar, H.J.W., 2016. Mesoscale features create hotspots of carbon uptake in the Antarctic Circumpolar. Curr., Deep Sea Res. Part II: Top. Stud. Oceanogr.. http://dx.doi.org/10.1016/ j.dsr2.2015.10.006.

Key, R.M., Tanhua, T., Olsen, A., Hoppema, M., Jutterström, S., Schirnick, C., van Heuven, S., Kozyr, A., Lin, X., Velo, A., Wallace, D.W.R., Mintrop, L., 2010. The CARINA data synthesis project: introduction and overview. Earth Syst. Sci. Data 2, 105-121. http://dx.doi.org/10.5194/essd-2-105-2010.

Khatiwala, S., Primeau, F., Hall, T., 2009. Reconstruction of the history of anthropogenic $\mathrm{CO}_{2}$ concentrations in the ocean. Nature 462, 346-U110. http://dx.doi.org/10.1038/ nature 08526.

Khatiwala, S., Tanhua, T., Mikaloff Fletcher, S., Gerber, M., Doney, C.S., Graven, H.D., Gruber, N., McKinley, G.A., Murata, A., Sabine, C., 2013. Global storage of anthropogenic carbon. Biogeosciences 10, 2169-2191. http://dx.doi.org/10.519/bg10-2169-2013.

Landschützer, P., Gruber, N., Bakker, D.C.E., Schuster, U., 2014. Recent variability of the 
global ocean carbon sink. Glob. Biogeochem. Cycle 28, 927-949. http://dx.doi.org/ 10.1002/2014GB004853.

Landschützer, P., Gruber, N., Haumann, F.A., Rödenbeck, C., Bakker, D.C.E., van Heuven, S., Hoppema, M., Metzl, N., Sweeney, C., Takahashi, T., Tilbrook, B. Wanninkhof, R., 2015. The reinvigoration of the Southern Ocean carbon sink. Science 349, 1221-1224. http://dx.doi.org/10.1126/science.aab2620.

Le Quéré, C., Rodenbeck, C., Buitenhuis, E.T., Conway, T.J., Langenfelds, R., Gomez, A., Labuschagne, C., Ramonet, M., Nakazawa, T., Metzl, N., Gillett, N., Heimann, M., 2007. Saturation of the Southern Ocean CO2 sink due to recent climate change. Science 316, 1735-1738.

Lenton, A., Tilbrook, B., Law, R.M., Bakker, D., Doney, S.C., Gruber, N., Ishii, M. Hoppema, M., Lovenduski, N.S., Matear, R.J., McNeil, B.I., Metzl, N., Mikaloff Fletcher, S.E., Monteiro, P.M.S., Rödenbeck, C., Sweeney, C., Takahashi, T., 2013. Sea-air CO2 fluxes in the Southern Ocean for the period 1990-2009. Biogeosciences 10, 4037-4054. http://dx.doi.org/10.5194/bg-10-4037-2013.

Lenton, A., Matear, R.J., 2007. Role of the Southern Annular Mode (SAM) in Southern Ocean CO2 uptake. Global Biogeochem. Cycles 21, GB2016. http://dx.doi.org/ $10.1029 / 2006$ GB002714.

Levine, N.M., Doney, S.C., Wanninkhof, R., Lindsay, K., Fung, I.Y., 2008. Impact of ocean carbon system variability on the detection of temporal increases in anthropogenic $\mathrm{CO}_{2}$. J. Geophys. Res. 113, $\mathrm{C} 03019$.

McCartney, M.S., 1977. Subantarctic mode water. (George Deacon 70th Anniversary Volume)In: Angel, M. (Ed.), A Voyage of Discovery. Pergamon Press, Oxford, U.K, $103-119$.

Mikaloff Fletcher, S.E., Gruber, N., Jacobson, A.R., Doney, S.C., Dutkiewicz, S., Gerber, M., Follows, M., Joos, F., Lindsay, K., Menemenlis, D., Mouchet, A., Muller, S.A., Sarmiento, J.L., 2006. Inverse estimates of anthropogenic $\mathrm{CO}_{2}$ uptake, transport, and storage by the ocean. Glob. Biogeochem. Cycle 20, GB2002.

Nierenberg, W.A., Nowlin, W.D., 1985. Physical, chemical and in-situ CTD data from the AJAX Expedition in the South Atlantic Ocean aboard RV Knorr 275. Scripps Institution of Oceanography, San Diego, CA, USA, 275.

Olsen, A., Key, R.M., van Heuven, S., Lauvset, S.K., Velo, A., Lin, X., Schirnick, C., Kozyr, A., Tanhua, T., Hoppema, M., Jutterström, S., Steinfeldt, R., Jeansson, E., Ishii, M., Pérez, F.F., Suzuki, T., 2016. The Global Ocean Data Analysis Project version 2 (GLODAPv2) - an internally consistent data product for the world ocean. Earth Syst. Sci. Data 8, 297-323. http://dx.doi.org/10.5194/essd-8-297-2016.

Orsi, A.H., Whitworth Iii, T., Nowlin, W.D., Jr., 1995. On the meridional extent and fronts of the Antarctic Circumpolar Current. Deep Sea Res. Part I: Oceanogr. Res. Pap. 42, 641-673. http://dx.doi.org/10.1016/0967-0637(95)00021-W.

Pardo, P.C., Pérez, F.F., Khatiwala, S., Ríos, A.F., 2014. Anthropogenic $\mathrm{CO}_{2}$ estimates in the Southern Ocean: storage partitioning in the different water masses. Prog. Oceanogr. 120, 230-242. http://dx.doi.org/10.1016/j.pocean.2013.09.005.

Peng, T.-H., Wanninkhof, R., 2010. Increase in anthropogenic $\mathrm{CO}_{2}$ in the Atlantic Ocean in the last two decades. Deep Sea Res. Part I: Oceanogr. Res. Pap. 57, 755-770. http://dx.doi.org/10.1016/j.dsr.2010.03.008.

Peterson, R.G., Whitworth, T., 1989. The subantarctic and polar fronts in relation to deep water masses through the southwestern Atlantic. J. Geophys. Res.: Ocean. 94, 10817-10838. http://dx.doi.org/10.1029/JC094iC08p10817.

Plancherel, Y., Rodgers, K.B., Key, R.M., Jacobson, A.R., Sarmiento, J.L., 2012. Role of regression model selection and station distribution on the estimation of oceanic anthropogenic carbon change by eMLR. Biogeosci. Discuss. 9, 14589-14638. http:// dx.doi.org/10.5194/bgd-9-14589-2012.

Sabine, C.L., Feely, R.A., Gruber, N., Key, R.M., Lee, K., Bullister, J.L., Wanninkhof, R., Wong, C.S., Wallace, D.W.R., Tilbrook, B., Millero, F.J., Peng, T.-H., Kozyr, A., Ono, T., Rios, A.F., 2004. The Oceanic sink for Anthropogenic $\mathrm{CO}_{2}$. Science 305, 367-371.

Sabine, C.L., Feely, R.A., Millero, F., Dickson, A.G., Langdon, C., Mecking, S., Greeley, D., 2008. Decadal changes in Pacific Carbon. J. Geophys. Res. 113, C07021. http:// dx.doi.org/10.1029/2007JC004577.

Sabine, C.L., Tanhua, T., 2010. Estimation of anthropogenic $\mathrm{CO}_{2}$ inventories in the ocean. Annu. Rev. Mar. Sci. 2, 175-198. http://dx.doi.org/10.1146/annurevmarine-120308-080947.

Sokolov, S., Rintoul, S.R., 2009. Circumpolar structure and distribution of the Antarctic Circumpolar Current fronts: 1. Mean circumpolar paths. J. Geophys. Res.: Ocean. 114, C11018. http://dx.doi.org/10.1029/2008JC005108.

Stöven, T., Tanhua, T., Hoppema, M., Bullister, J.L., 2015. Perspectives of transient tracer applications and limiting cases. Ocean Sci. 11, 699-718. http://dx.doi.org/ 10.5194/os-11-699-2015.

Strass, H., Leach, H., Prandke, H., Donnelly, M., Bracher, A., Wolf-Gladrow, D.A., 2016 The physical environmental conditions for biogeochemical differences along the Antarctic Circumpolar Current in the Atlantic Sector during late austral summer 2012. Deep Sea Res. - II, (in this issue).

Takahashi, T., Sutherland, S.C., Wanninkhof, R., Sweeney, C., Feely, R.A., Chipman, D.W., Hales, B., Friederich, G., Chavez, F., Sabine, C., Watson, A., Bakker, D.C.E., Schuster, U., Metzl, N., Yoshikawa-Inoue, H., Ishii, M., Midorikawa, T., Nojiri, Y., Kortzinger, A., Steinhoff, T., Hoppema, M., Olafsson, J., Arnarson, T.S., Tilbrook, B., Johannessen, T., Olsen, A., Bellerby, R., Wong, C.S., Delille, B., Bates, N.R., de Baar, H.J.W., 2009. Climatological mean and decadal change in surface ocean $\mathrm{pCO}_{2}$, and net sea-air $\mathrm{CO}_{2}$ flux over the global oceans (vol 56, pg 554, 2009). Deep-Sea Res. I 56, 2075-2076. http://dx.doi.org/10.1016/j.dsr2.2008.12.009.

Tanhua, T., Olsson, K.A., Fogelqvist, E., 2004. A first study of $\mathrm{SF}_{6}$ as a transient tracer in the Southern Ocean. Deep-Sea Res. II 51, 2683-2699.

Tanhua, T., Körtzinger, A., Friis, K., Waugh, D.W., Wallace, D.W.R., 2007. An estimate of anthropogenic $\mathrm{CO}_{2}$ inventory from decadal changes in ocean carbon content. Proc. Natl. Acad. Sci. U.S.A. 104, 3037-3042. http://dx.doi.org/10.1073/ pnas.0606574104.

Tanhua, T., van Heuven, S., Key, R.M., Velo, A., Olsen, A., Schirnick, C., 2010. Quality control procedures and methods of the CARINA database. Earth Syst. Sci. Data 2, 35-49.

Tanhua, T., Waugh, D.W., Bullister, J.L., 2013. Estimating changes in ocean ventilation from the early $1990 \mathrm{~s}$ CFC- 12 and late $2000 \mathrm{~s} \mathrm{SF}_{6}$ measurements. Geophys. Res. Lett. 40, 1-6. http://dx.doi.org/10.1002/grl.50251.

Thacker, W.C., 2012. Regression-based estimates of the rate of accumulation of anthropogenic CO2 in the ocean: a fresh look. Mar. Chem. 132-133, 44-55. http:// dx.doi.org/10.1016/j.marchem.2012.02.004.

Tsuchiya, M., Talley, L.D., McCartney, M.S., 1994. Water-mass distributions in the western South Atlantic; A section from South Georgia Island (54S) northward across the equator. J. Mar. Res. 52, 55-81. http://dx.doi.org/10.1357/ 0022240943076759.

van Heuven, S.M.A.C., Hoppema, M., Huhn, O., Slagter, H.A., de Baar, H.J.W., 2011. Direct observation of increasing $\mathrm{CO}_{2}$ in the Weddell Gyre along the Prime Meridian during 1973-2008. Deep-Sea Res Pt II-Top. Stud. Oceanogr. 58, 2613-2635. http:// dx.doi.org/10.1016/j.dsr2.2011.08.007.

Wallace, D.W.R., 1995. Monitoring Global Ocean Carbon Inventories, Ocean Observing System Development Panel background. Texas A\& M Univeristy, Collage Station, TX.

Wanninkhof, R., Doney, S.C., Bullister, J.L., Levine, N.M., Warner, M., Gruber, N., 2010. Detecting anthropogenic $\mathrm{CO}_{2}$ changes in the interior Atlantic Ocean between 1989 and 2005. J. Geophys. Res. 115, C11028. http://dx.doi.org/10.1029/ $2010 J C 006251$.

Warner, M.J., Weiss, R.F., 1985. Solubilities of chlorofluorocarbons 11 and 12 in water and sea water. Deep-Sea Res. 32, 1485-1497.

Waugh, D.W., Hall, T.M., Haine, T.W.N., 2003. Relationship among tracer ages. J. Geophys. Res. 108. http://dx.doi.org/10.1029/2002JC001325.

Waugh, D.W., Primeau, F., DeVries, T., Holzer, M., 2013. Recent changes in the ventilation of the southern oceans. Science 339, 568. http://dx.doi.org/10.1126/ science. 1225411.

Whitworth, T., Nowlin, W.D., 1987. Water masses and currents of the Southern Ocean at the Greenwich Meridian. J. Geophys. Res.: Ocean. 92, 6462-6476. http:// dx.doi.org/10.1029/JC092iC06p06462.

Whitworth, T., Nowlin, W.D., Pillsbury, R.D., Moore, M.I., Weiss, R.F., 1991. Observations of the Antarctic Circumpolar Current and deep boundary current in the southwest Atlantic. J. Geophys. Res.: Ocean. 96, 15105-15118. http://dx.doi.org/ 10.1029/91JC01319.

Williams, N.L., Feely, R.A., Sabine, C.L., Dickson, A.G., Swift, J.H., Talley, L.D., Russell, J.L., 2015. Quantifying anthropogenic carbon inventory changes in the Pacific sector of the Southern Ocean. Mar. Chem. 174, 147-160. http://dx.doi.org/10.1016/ j.marchem.2015.06.015.

Wolf-Gladrow, D., 2013. The Expedition of the Research Vessel "Polarstern" to the Antarctic in 2012 (ANT-XXVIII/3). Alfred-Wegener-Institut Helmholtz-Zentrum für Polarund Meeresforschung, Bremerhaven, Germany,. 